\title{
Summary of the
}

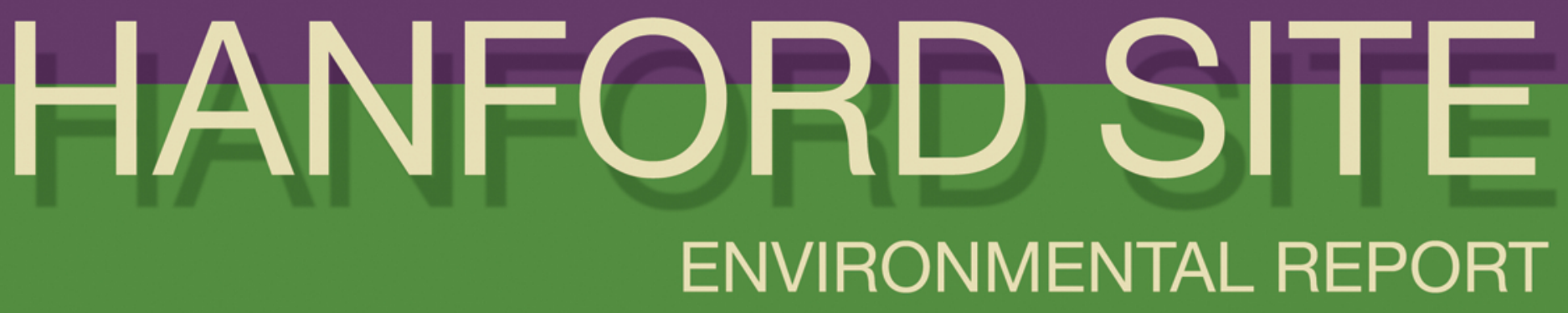

(1)

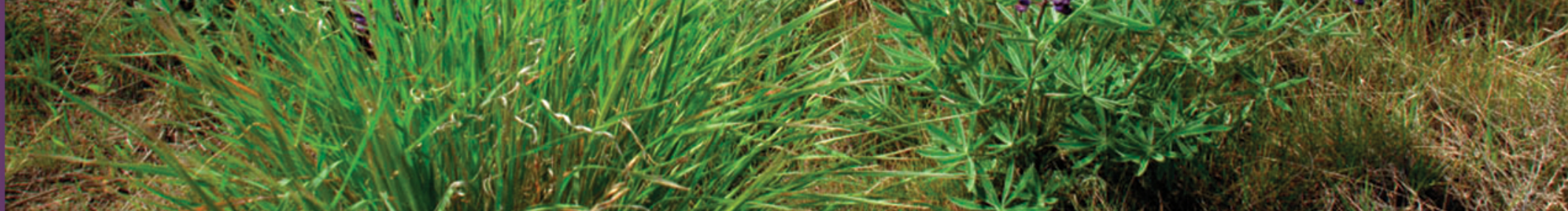

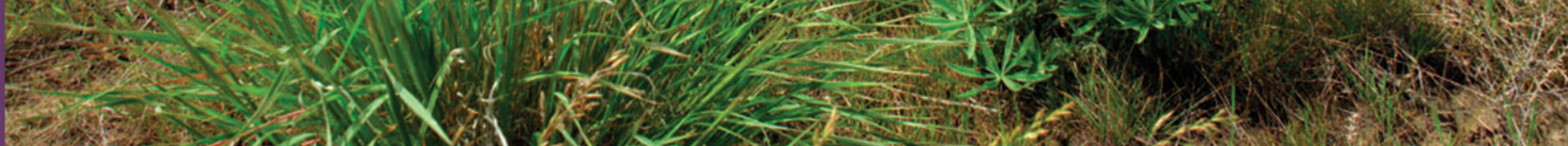

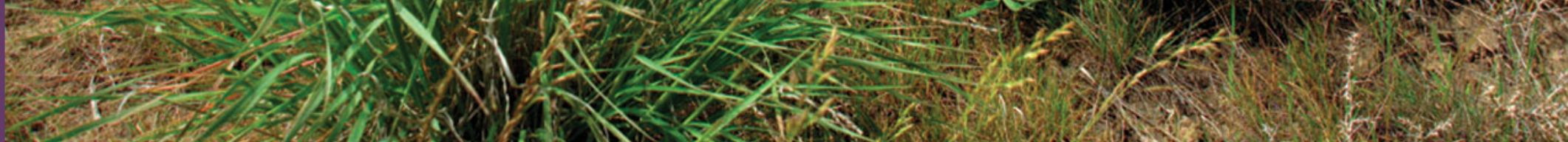
155. 26.

\section{for Calendar Year 2005}




\section{Summary of the}
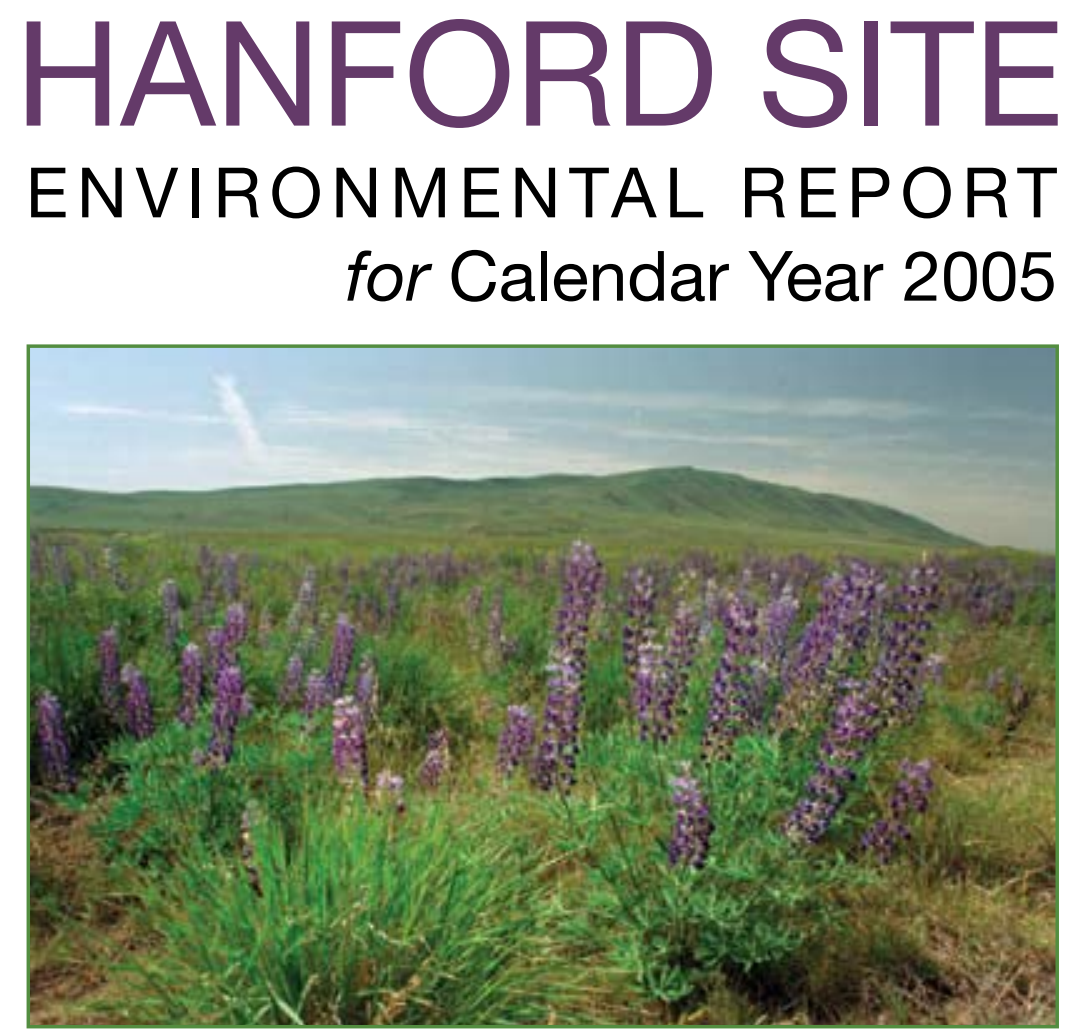

\section{EDITORS}

\section{R.W. HANF \\ L.F. MORASCH \\ T.M. POSTON \\ R.L. DIRKES}

\section{SEPTEMBER 2006}

Prepared for the U.S. Department of Energy by Pacific Northwest National Laboratory under contract DE-AC05-76RL01830, with contributions from Bechtel National, Inc.; CH2M HILL Hanford Group, Inc.; Fluor Hanford, Inc. and its subcontractors; and Washington Closure Hanford, LLC.

Pacific Northwest National Laboratory Richland, Washington 


\section{DISCLAIMER}

This report was prepared as an account of work sponsored by an agency of the United States Government. Reference herein to any specific commercial product, process,

or service by trade name, trademark, manufacturer, or otherwise does not necessarily constitute or imply its endorsement, recommendation, or favoring by the United States

Government or any agency thereof, or Battelle Memorial Institute.

The cover photo of lupine on the Hanford Site is from Lockheed Martin Information Technology, Richland, Washington. Rattlesnake Mountain is in the background. The cover design and document layout is by SB Neely, Pacific Northwest National Laboratory, Richland, Washington.

\section{Pacific Northwest National Laboratory}

Operated by Battelle for the

U.S. Department of Energy 


\section{CONTENTS}

Introduction 1

Overview of the Hanford Site and its Mission 2

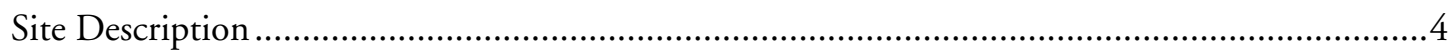

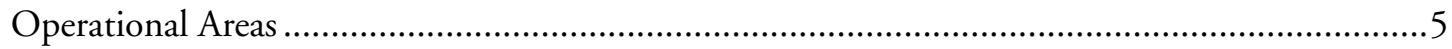

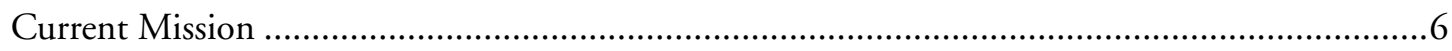

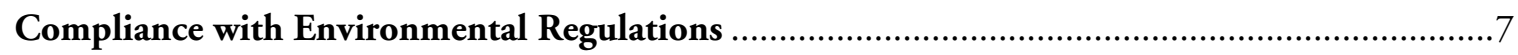

Hanford Federal Facility Agreement and Consent Order ......................................................

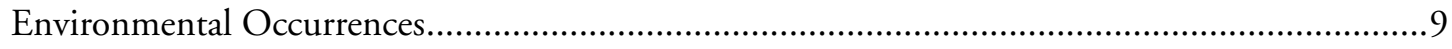

Pollution Prevention and Waste Minimization ...................................................................... 10

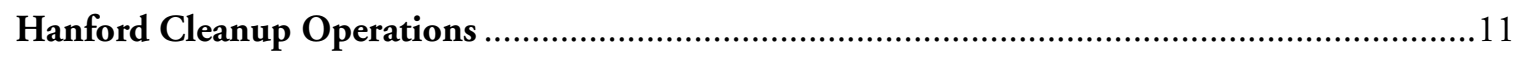

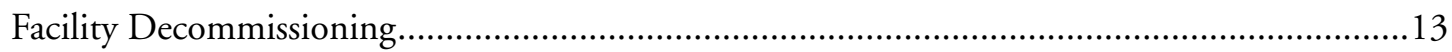

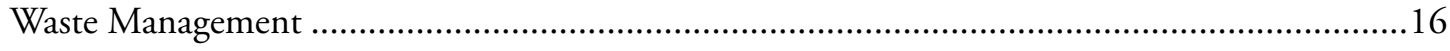

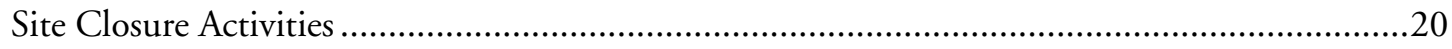

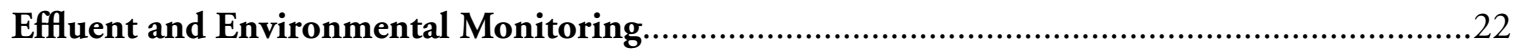

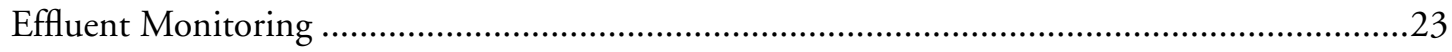

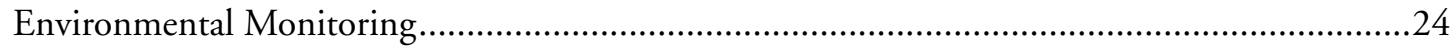

Potential Radiological Doses from 2005 Hanford Operations................................................28 


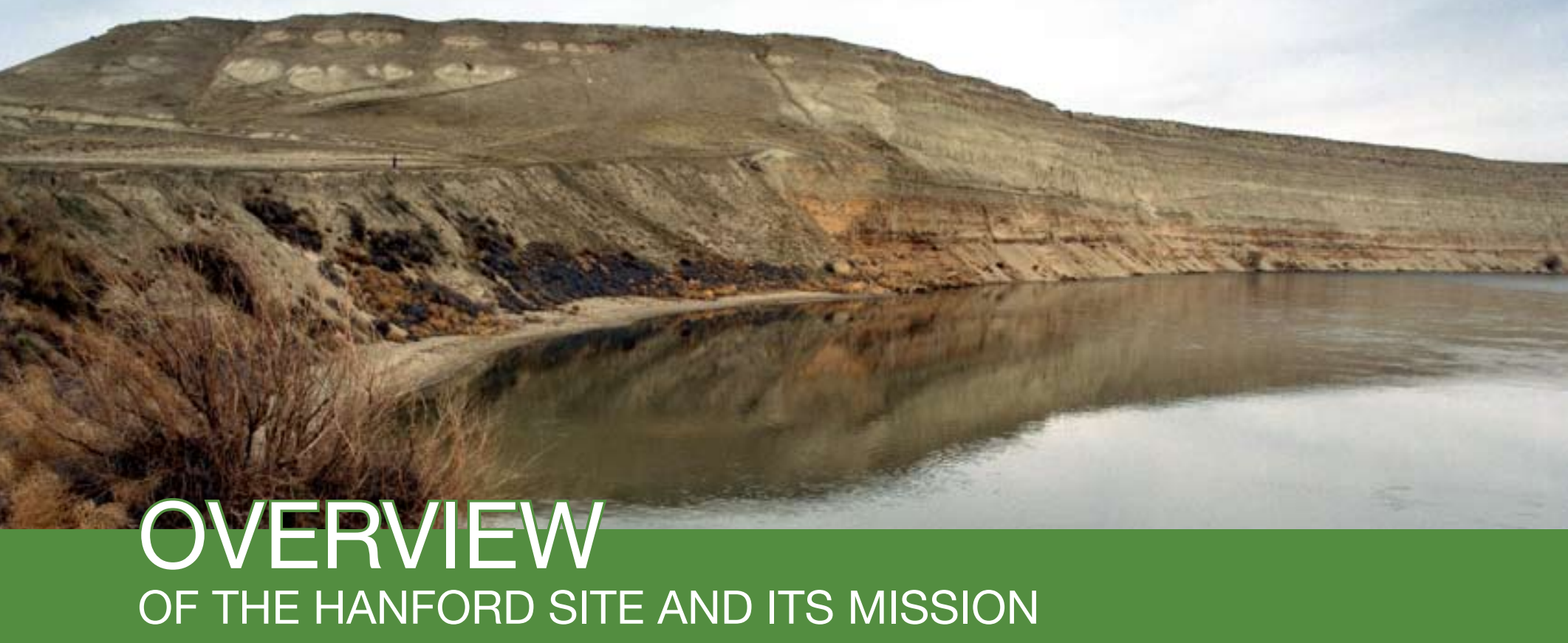

The White Bluffs are located on the Hanford Site along the eastern shore of the Columbia River in the Wahluke Unit of the Hanford Reach National Monument.
The Hanford Site lies within the semiarid Pasco Basin of the Columbia Plateau in southeastern Washington State. The site occupies an area of approximately 586 square miles located north of the city of Richland. A former plutonium production complex with nine nuclear reactors and associated processing facilities, the Hanford Site played a pivotal role in the production of materials for the nation's defense for more than 45 years, beginning in the 1940s with the Manhattan Project. Today, under the direction of the DOE, Hanford contractors are engaged in one of the world's largest environmental cleanup projects.

Public access to the site is restricted, and its large land area provides a buffer for the smaller areas on the site that historically were used for production of nuclear materials, waste storage, and waste disposal. The Columbia River flows eastward through the northern part of the Hanford Site and then turns south, forming part of the eastern site boundary.

In June 2000, the 305-square-mile Hanford Reach National Monument was established on the site by a Presidential Proclamation to protect the nation's only unimpounded stretch of the Columbia River above Bonneville Dam in the U.S. and a remnant of the shrub-steppe ecosystem that once blanketed the Columbia River basin.

In 2005, the DOE, U.S. Fish and Wildlife Service, and Washington Department of Fish and Wildlife managed the monument. The U.S. Fish and Wildlife 
Service administered three major management units of the monument totaling approximately 257 square miles. These included (1) the Fitzner/Eberhardt Arid Lands Ecology Reserve Unit, a 120-square-mile tract of land in the southwestern portion of the Hanford Site; (2) the Saddle Mountain Unit, a 50-square mile tract of land located north-northwest of the Columbia River and generally south and east of State Highway 24; and (3) the Wahluke Unit, an 87-square mile tract of land located north and east of both the Columbia River and the Saddle Mountain Unit.

The portion of the monument administered only by the DOE included the McGee Ranch-Riverlands Unit (north and west of State Highway 24 and south of the Columbia River), the Columbia River islands in Benton County, the Columbia River corridor (one-quarter mile inland from the shoreline) on the Benton County side of the river, and the sand dunes area located along the Hanford side of the Columbia River north of the commercial nuclear power plant owned and operated by Energy Northwest.

Approximately 400 acres along the north side of the Columbia River, west of the Vernita Bridge and south of State Highway 243, were managed by the Washington Department of Fish and Wildlife.

\section{HANFORD AT A GLANCE}

\section{Location}

Dominant Features

Size

Employees

Mission

Budget

Site Management
The U.S. Department of Energy's Hanford Site is located in southeastern Washington State near the city of Richland.

Rattlesnake Mountain on the Fitzner/Eberhardt Arid Lands Ecology Reserve Unit of the Hanford Reach National Monument rises 3,525 feet above sea level, and the Columbia River flows through the northern part of the site.

The site covers approximately 586 square miles.

The DOE and its contractors employ approximately 7,000 workers.

Hanford's mission is to safely clean up and manage the site's legacy facilities and waste and reduce the size of the site.

The site's fiscal year 2005 budget was approximately $\$ 1.8$ billion.

The DOE's Richland Operations Office and Office of River Protection jointly manage the Hanford Site through several contractors and their subcontractors. Each contractor is responsible for the safe, environmentally sound, maintenance and management of its activities or facilities; for waste management; for monitoring all discharges to the environment; and for complying with all local, state, and federal regulations. The DOE, U.S. Fish and Wildlife Service, and the Washington Department of Fish and Wildlife each manage portions of the Hanford Reach National Monument. 


\section{SITE DESCRIPTION}

The Hanford Site is a relatively undeveloped area of shrub-steppe habitat (a drought-resistant, shrub and grassland ecosystem) that contains a rich diversity of plant and animal species. This area has been protected from disturbance, except for fire, over the past 60 years. This protection has allowed plants and animals that have been displaced by agriculture and development in other parts of the Columbia Basin to thrive at Hanford.

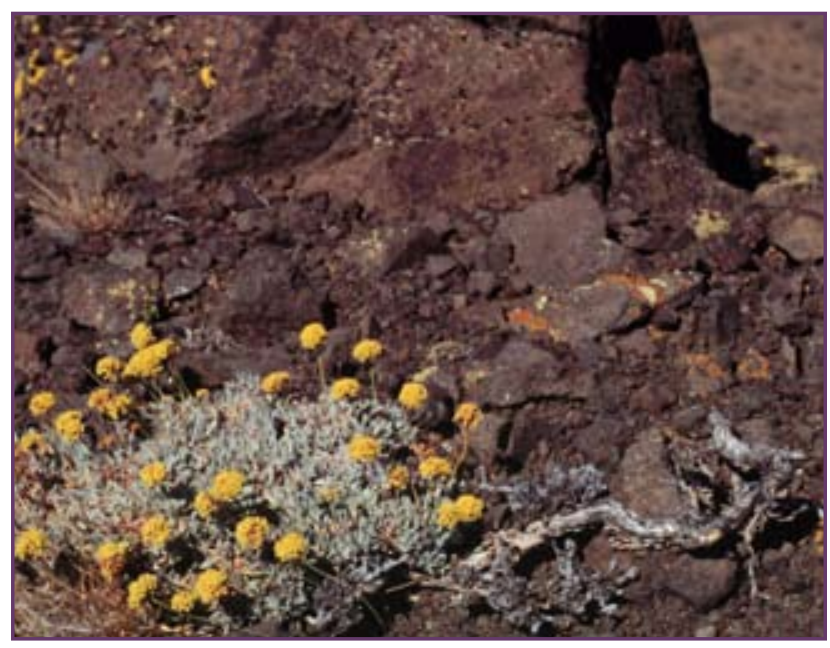

Umtanum desert buckwheat is a plant species proposed for federal listing as threatened or endangered.
Deer and elk are the major large mammals found on Hanford Site. A herd of Rocky Mountain elk has inhabited the site since 1972. Coyotes also are plentiful on the site. The Great Basin pocket mouse is the most abundant mammal on the site. Numerous species of waterfowl and shorebirds inhabit the river including egrets, white pelicans, and herons.

Spring Chinook salmon and steelhead are two fish species listed as threatened or endangered by the federal government under the Endangered Species Act of 1973. Other federally listed species include the bald eagle. Western sage grouse and two plants, the Umtanum desert buckwheat and the White Bluffs bladder pod are also proposed as candidate species for federal listing. Additionally, the state of Washington has listed 15 plant species and 5 birds as state threatened or endangered.

There are two types of natural aquatic habitat on the Hanford Site. One is the Columbia River and associated wetlands, and the second is upland aquatic sites. The upland sites include small springs and streams located mainly on or near Rattlesnake Mountain on the Fitzner/Eberhardt Arid Lands Ecology

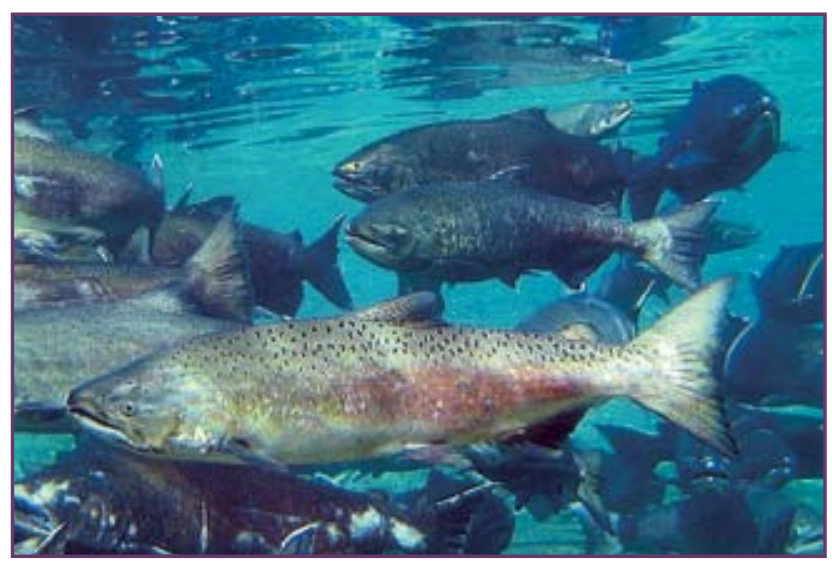

Reserve Unit of the Hanford Reach National Monument (e.g., Rattlesnake Springs, Dry Creek, Snively Springs) and West Lake, a small pond near the 200 Areas.

Salmon and steelhead are the local fish species of most interest to sport fishermen and Native American tribes and are commonly consumed by both groups. Fall Chinook salmon spawn in the Hanford Reach of the Columbia River, the major natural spawning area for this fish in the mainstem Columbia River. Aerial surveys of the Hanford Reach during 2005 detected approximately 7,890 redds (salmon spawning nests); this is a slight decrease from the redd count $(8,470)$ in 2004 .

Chinook salmon spawn in the Hanford Reach of the Columbia River. 


\section{OPERATIONAL AREAS}

The major DOE operational, administrative, and research areas on and around the Hanford Site include the following:

- 100 Areas - located along the south shore of the Columbia River. These are the sites of nine retired plutonium production reactors and once occupied approximately 4 square miles.

- 200-West and 200-East Areas - centrally located on the site's Central Plateau. These areas were once used for plutonium separation operations and are approximately 5 and 7 miles south and west of the Columbia River and cover approximately 6 square miles.

- 300 Area - located just north of Richland. From the early 1940 s until the advent of the cleanup mission, most research and development activities at Hanford were carried out in the 300 Area. This area covers approximately 0.6 square mile.

- 400 Area - located northwest of the 300 Area; covers approximately 0.23 square mile. The Fast Flux Test Facility (currently being decommissioned) is located in this area.

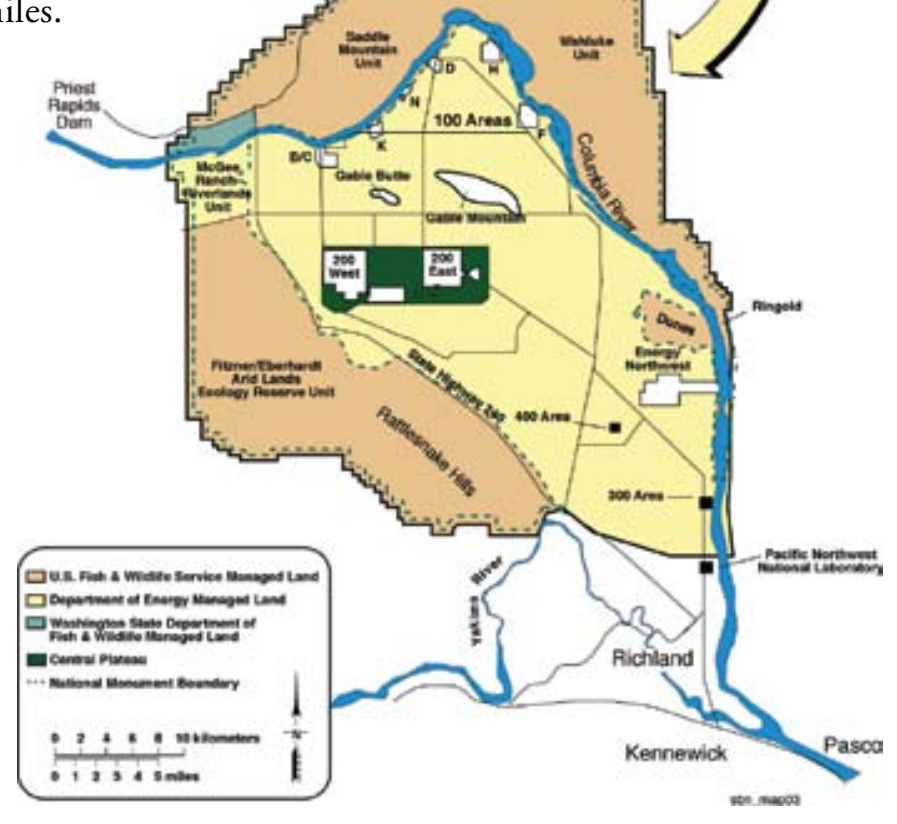

- 600 Area - includes all of the Hanford Site not occupied by the 100, 200, 300, and 400 Areas.

This map shows management units on the Hanford Reach National Monument and the operational areas of the Hanford Site.

- Former 1100 Area - located between the 300 Area and the city of Richland; the area covers 768 acres. In 1998, this area was transferred to the Port of Benton as part of the DOE's Richland Operations Office economic diversification efforts and is no longer part of the Hanford Site. DOE contractors continue to lease facilities in this area.

- Richland North Area (off the site) - includes the Pacific Northwest National Laboratory and other DOE and contractor facilities, mostly office buildings and laboratories in the northern part of the city of Richland.

- 700 Area (off the site) - an area of DOE administrative buildings in central Richland.

The Hanford Site lies within the semi-arid Pasco Basin of the Columbia platean in sontheastern Washington state.

- Volpentest Hazardous Materials Management and Emergency Response Training and Education Center (also called HAMMER) - a worker safety-training facility located on the site near the city of Richland. It consists of an 80-acre main site and a 10,000-acre law enforcement and security training site. 
The DOE's primary mission at the Hanford Site is to accelerate completion of waste cleanup.

\section{CURRENT MISSION}

For more than 40 years, Hanford Site facilities were dedicated primarily to the production of plutonium for national defense and management of the resulting waste. Hanford was the first plutonium production site in the world. In recent years, efforts at the site have focused on developing new waste treatment and disposal technologies and characterizing and cleaning up contamination left from historical operations. Physical challenges at the Hanford Site include millions of gallons of highly radioactive liquid waste in 177 underground storage tanks, 2,300 tons of spent nuclear fuel, 9 tons of plutonium in various forms, about 25 million cubic feet of buried or stored solid waste, about 77 square miles of groundwater contaminated with chemicals and radionuclides above drinking water standards, more than 1,700 former waste disposal sites, and about 500 contaminated facilities.

Currently, the DOE's primary mission is to accelerate completion of waste cleanup. The Performance Management Plan for the Accelerated Cleanup of the Hanford Site states that the cleanup mission includes six strategies:

- Restoring the Columbia River corridor by accelerating clean up Hanford Site sources of radiological and chemical contamination that threaten the air, groundwater, or Columbia River. It is expected that most river corridor projects will be completed by 2012 .

- Ending the tank waste program by 2033 by accelerating waste retrieval, increasing the capacity of the Waste Treatment Plant (under construction), and starting the process of closing underground waste storage tanks.

- Accelerating the cleanup of Hanford's other urgent risks.

- Accelerating treatment and disposal of mixed low-level waste and the retrieval of transuranic waste and its shipment off the site.

- Accelerating cleanup of excess facilities on the Central Plateau (200-East and 200-West Areas).

- Accelerating cleanup and protection of groundwater beneath the Hanford Site.

The DOE Richland Operations Office and DOE Office of River Protection jointly manage the Hanford Site through several contractors and their subcontractors. The DOE Richland Operations Office manages legacy cleanup, research, and other programs at the Hanford Site. The DOE Office of River Protection manages the DOE's largest, most complex environmental cleanup project - Hanford's tank waste retrieval, treatment, and disposal. 


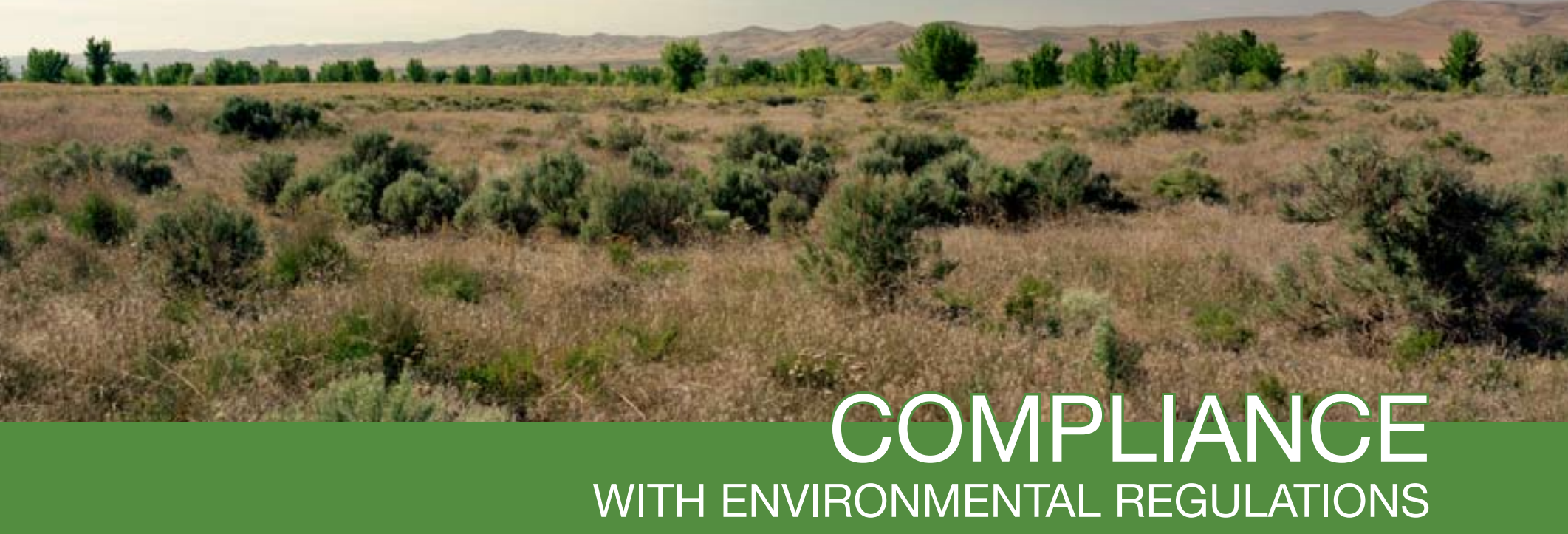

Environmental standards and regulations applicable at DOE facilities fall into three categories: (1) DOE directives; (2) federal legislation and executive orders; and (3) state and local statutes, regulations, and requirements.

Several federal, state, and local government agencies monitor and enforce compliance with applicable environmental regulations at the Hanford Site. Major agencies include the U.S. Environmental Protection Agency (EPA), Washington State Department of Ecology, Washington State Department of Health, and Benton Clean Air Authority. These agencies issue permits, review compliance reports, participate in joint monitoring programs, inspect facilities and operations, and/or oversee compliance with applicable regulations. There are specific requirements, actions, plans, and schedules identified in the Hanford Federal Facility Agreement and Consent Order (also known as the Tri-Party Agreement) and other compliance or consent agreements.

Both the DOE Richland Operations Office and DOE Office of River Protection recognize the importance of maintaining a program of self-assessment and regulatory reporting to assure that environmental compliance is achieved and maintained at the Hanford Site.

The site's compliance with federal acts in 2005 is summarized in the table on the following page.
The Hanford Site is a relatively undeveloped area of shrub-steppe (a drought-resistant shrub and grassland ecosystem) that contains a rich diversity of plant and animal species. 


\section{COMPLIANCE WITH FEDERAL ACTS AT THE HANFORD SITE IN 2005}

\section{Regulation}

American Indian Religious Freedom Act, Antiquities Act, Archaeological and Historic Preservation Act, Archaeological Resources Protection Act, Historic Sites, Buildings, and Antiquities Act, National Historic Preservation Act, and Native American Graves Protection and Repatriation Act

Atomic Energy Act

Clean Air Act

Clean Water Act

Comprehensive Environmental

Response, Compensation, and Liability Act (CERCLA)

Emergency Planning and Community Right-to-Know Act

Endangered Species Act

Federal Insecticide, Fungicide, and Rodenticide Act

Migratory Bird Treaty Act

National Environmental Policy Act

Resource Conservation and Recovery Act (RCRA)

\section{Safe Drinking Water Act}

Toxic Substances Control Act

\section{What it Covers}

Cultural resources.

Management of radioactive materials.

Air quality, including emissions from facilities and from unmonitored sources.

Discharges to U.S. waters.

Sites already contaminated by hazardous materials.

The public's right to information about hazardous materials in the community and establishes emergency planning procedures.

Rare species of plants and animals.

Storage and use of pesticides.

Migratory birds or their feathers, eggs, or nests.

Environmental impact statements for federal projects.

Tracking hazardous waste from generator to treatment, storage, or disposal.

Drinking water systems operated by the DOE at Hanford.

Primarily regulation of chemicals called polychlorinated biphenyls (PCBs).

\section{Status}

One hundred ninety cultural resource reviews on the Hanford Site were requested. The DOE determined that 156 were not the type of activities with potential to affect cultural resources and were exempt from review; six requests were exempted by programmatic agreement; seven requests required walk throughs; twenty-three requests required full reviews.

The DOE issued directives, standards, and guidance documents.

The Washington State Department of Health issued two noncompliance documents regarding emissions at the 296-B-28 and 296P-43 emission units and the 296-S-21 stack at the 222-S Laboratory.

The Hanford Site had one National Pollutant Discharge Elimination System Permit, one storm water permit, and several State Wastewater Discharge Permits. There were no permit violations in 2005.

Remediation work on these sites followed CERCLA requirements. During 2005, four corrective actions were made: (1) installed new signs on 100 Areas haul roads, (2) evaluated the 300 Area surveillance and maintenance program, (3) evaluated the procedure for including deed information in the waste information data system, and (4) evaluated the waste information data system to improve access.

The Hanford Site met the reporting requirements contained in this act.

Spring Chinook salmon and steelhead are listed as threatened or endangered by the federal government as well as the bald eagle. Western sage grouse and two plants, the Umtanum desert buckwheat and the White Bluffs bladderpod are also proposed as candidate species for federal listing. Additionally, the state of Washington has listed 15 plant species and 5 birds as state threatened or endangered.

At the Hanford Site, pesticides are applied by commercial pesticide operators licensed by the state.

Hanford activities used the ecological review process as needed to minimize any adverse effects to migratory birds. There are over 100 species of birds that occur on the Hanford Site that are protected by this act.

Environmental impact statements and environmental assessments were prepared or conducted as needed. In 2005, the DOE prepared one draft environmental assessment and announced its intention to prepare an environmental impact statement for tank closure to include the Fast Flux Test Facility.

The Washington State Department of Ecology identified one noncompliance issue during 2005: An inspection of the 340 facility raised concerns about data and information on the vault tanks. All corrective measures were completed.

There were 11 public water systems on the Hanford Site. The systems were monitored for radiological contaminants and all contaminant concentrations in 2005 met the requirements of the Washington State Department of Health.

Non-radioactive waste and radioactive PCB waste in certain categories were disposed of in accordance with 40 CFR 761. The EPA approved the Risk-Based Disposal activities during 2005 for retrieval of waste from single-shell tanks and for North Load-Out Pit sludge from the K Basins project. 


\section{HANFORD FEDERAL FACILITY AGREEMENT AND CONSENT ORDER}

A key element in Hanford's compliance program is the Hanford Federal Facility Agreement and Consent Order (TriParty Agreement). The Tri-Party Agreement is an agreement among the Washington State Department of Ecology, EPA, and DOE to achieve compliance with the remedial action provisions of the Comprehensive Environmental Response, Compensation, and Liability Act (CERCLA) and with the treatment, storage, and disposal unit regulation and corrective action provisions of the Resource Conservation and Recovery Act (RCRA). During 2005, there were 37 specific Tri-Party Agreement cleanup milestones scheduled for completion: 35 were completed on or before their required due dates, 1 was completed beyond its established due date, and 1 was not yet complete at the end of 2005 .

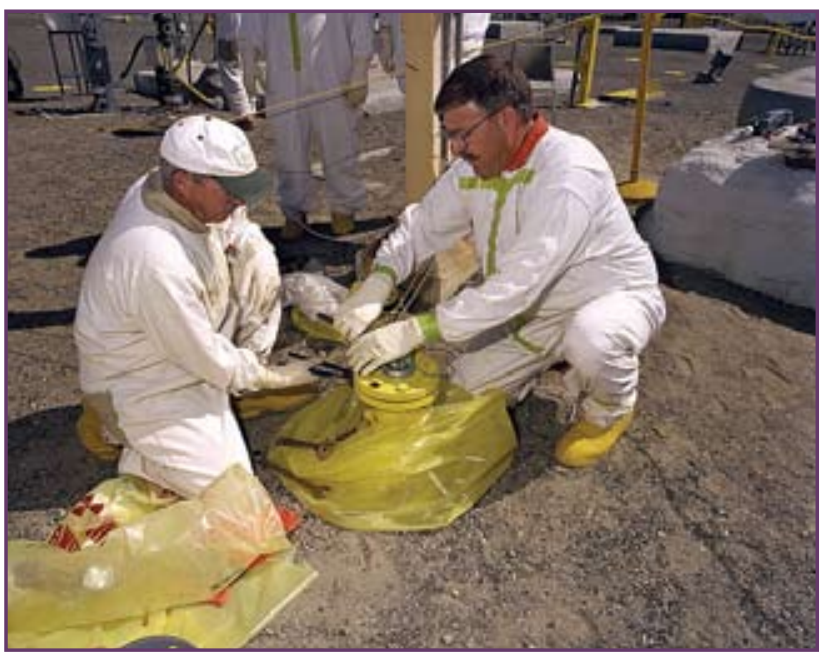

During 2005, 15 negotiated change requests to the Tri-Party Agreement were

Some Tri-Party Agreement milestones completed in 2005 were related to work on Hanford waste storage tanks. approved. These change requests may be viewed in their entirety in the TriParty Agreement Administrative Record at http://www2.hanford.gov/arpir/.

\section{ENVIRONMENTAL OCCURRENCES}

Environmental releases of radioactive and regulated materials from the Hanford Site are reported to the DOE and other federal and state agencies as required by law. The specific agencies notified depend on the type, amount, and location of the individual occurrence. The Hanford Site Occurrence Notification Center maintains both a computer database and a hardcopy file of event descriptions and corrective actions. Six significance categories have been established including: $\mathrm{OE}$ (operational emergency), $\mathrm{R}$ (recurring), 1 (significant impact), 2 (moderate impact), 3 (minor impact), and 4 (some impact).

In 2005, there were no occurrences ranked as significance category OE, R, 1 , or 2 on the Hanford Site. There were four Category 3 occurrences with potential environmental implications on the Hanford Site in 2005: (1) Excessive beryllium levels were discovered outside Building 313. Work was suspended until additional sampling was conducted; when work continued workers were required to wear respiratory protection. (2) An instructor at the Patrol Training Academy accidentally started a brush fire during a training exercise. The fire was contained within 3 hours and there The Hanford Site Occhrerence Notification center maintains both a computer database and a hardcopy file of event descriptions and cortective actions. 
In 2005, the Pollation

Drevention and Waste

Minimization Drogram

reported recycling of 3,897

tons of sanitary and

hazardons waste. storms on the Hanford Site resulted in debris consisting of paper, glass, and cloth being blown outside of a posted contamination area in the 300 Area. Technicians conducted surveys and no smearable contamination was detected. (4) During the same March 2005 wind storms, contaminated plastic debris was blown outside of a posted contamination area near the Environmental Restoration Disposal Facility.

There were three Category 4 events during 2005: (1) A radiological air sample collected at the boundary of the 100-N Area and a lapel sample showed elevated levels of airborne contamination. The elevated levels were attributed to demolition of contaminated concrete, inadequate dust suppression techniques, and local meteorology. (2) A grass fire occurred on the Saddle Mountain Unit of the Hanford Reach National Monument on July 5, 2005. The fire was extinguished before midnight that same day. (3) A grass fire occurred on the Wahluke Unit of the Hanford Reach National Monument on August 9, 2005. The fire was contained the next day.

\section{POLLUTION PREVENTION AND WASTE MINIMIZATION}

This program is a continuing effort to reduce the quantity and toxicity of hazardous, radioactive, mixed, and sanitary waste generated at Hanford. The program fosters the conservation of resources and energy, reduction in the use of hazardous substances, and prevention or minimization of pollutant releases to all environmental media from all operations and site cleanup activities. The purchase of environmentally preferable products containing recycled material achieved $100 \%$ of the 2005 goal at the Hanford Site.

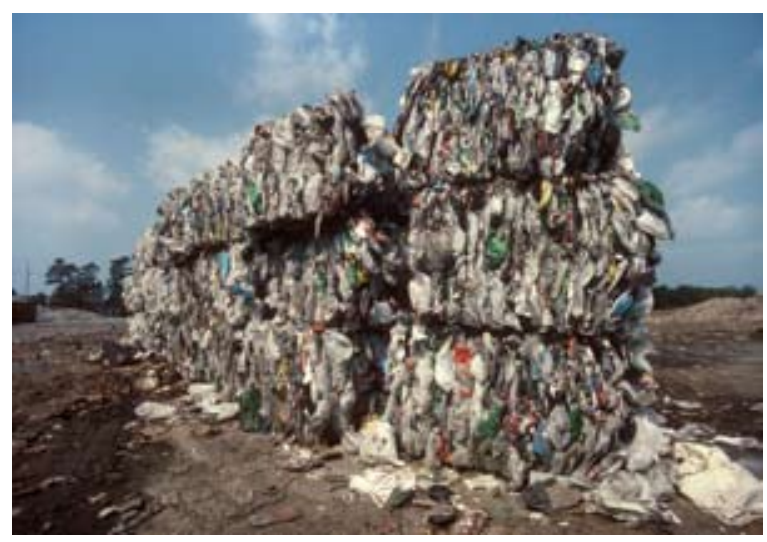

The Hanford Site met the fiscal year 2005 Secretarial Goals for low-level waste, mixed low-level waste, hazardous and sanitary routine waste generation, and recycling. The recycled sanitary waste included 376 tons of office and mixed paper, 867 tons of iron/steel, 63 tons of non-ferrous metal, and 83 tons of appliances and furniture. The recycled hazardous waste included such things as 486 tons of PCB oil, 55 tons of lead, and 48 tons of excess chemicals.

The Hanford Site generated 40,014 cubic yards of cleanup and stabilization waste and did not meet the $10 \%$ cleanup stabiliza-

The Hanford Site met the fiscal year 2005 Secreterial Goals for recycling. tion goal of 36,659 cubic yards. Due to changing work scope and other uncertainties, predicting the annual volume of Hanford waste is not precise. 


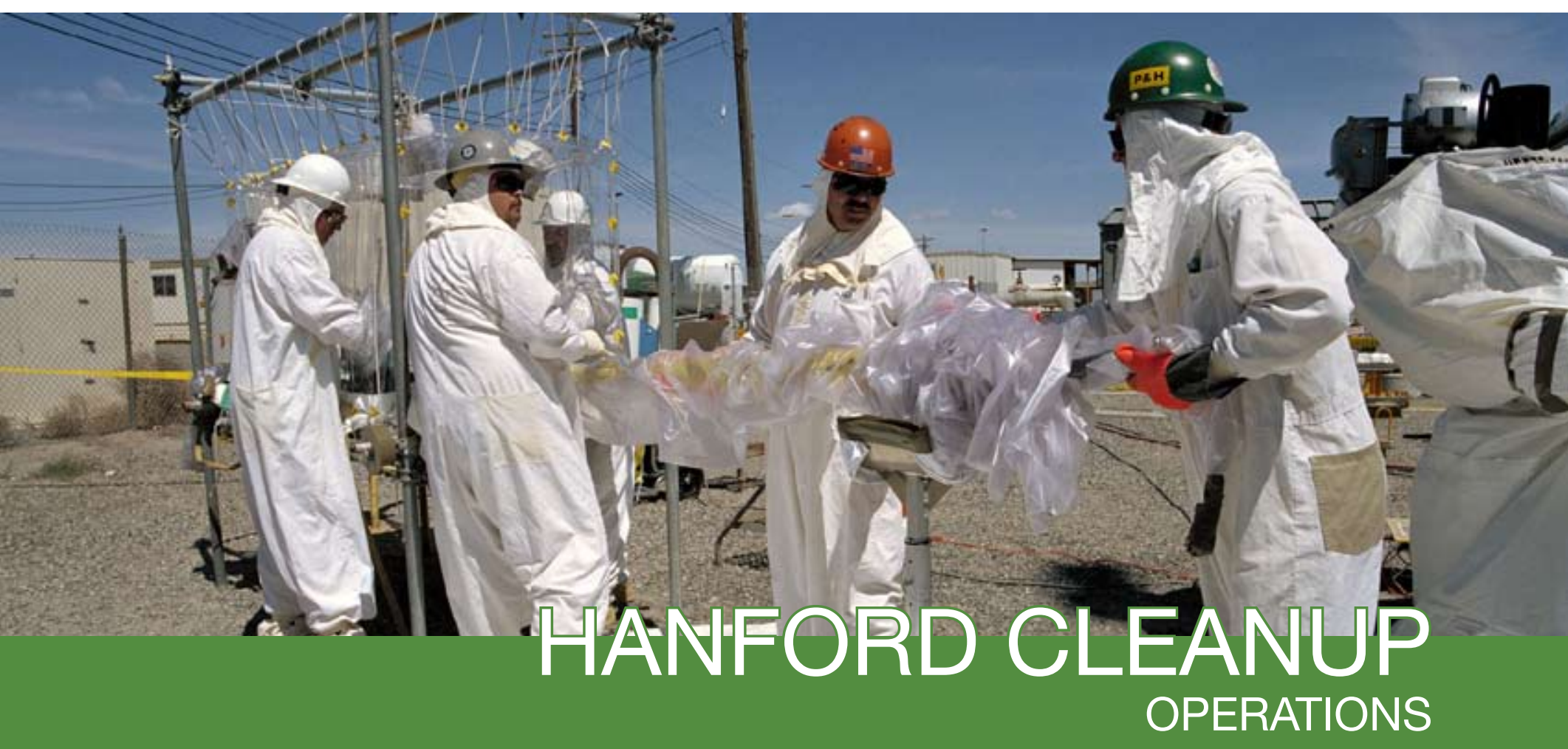

A major focus of the DOE's environmental management mission at Hanford is cleanup and management of the site's legacy waste from more than 45 years of nuclear materials production. The work involves safe storage, treatment, and final disposal of a large amount and variety of radioactive and chemical materials. It also involves remediating hundreds of inactive waste disposal sites and stabilizing inactive facilities and the materials inside them to prevent leaks or limit radiation exposures. Environmental restoration and pollution prevention are key parts of the environmental management mission.

Waste from Hanford cleanup operations is classified as either radioactive, non-radioactive, mixed, dangerous, or non-dangerous. Radioactive waste is categorized as transuranic, high-level, and low-level. Mixed waste has both radioactive and dangerous non-radioactive substances. Dangerous waste contains hazardous nonradioactive substances. Dangerous waste is treated, stored, and prepared for disposal at several Hanford Site facilities or is shipped offsite for disposal or destruction. Some types of waste, such as lead-acid batteries and aerosol products, are shipped offsite for recycling. Annual reports provide information about the dangerous waste generated, treated, stored, and disposed of on the Hanford Site.

Hanford cleanup involves work in the single- and double-shell tank farms. 
Non-dangerous waste is waste that does not contain hazardous or radioactive substances. Non-dangerous waste generated at the Hanford Site historically was buried onsite. However, beginning in 1999, non-dangerous waste has been disposed of at an offsite landfill.

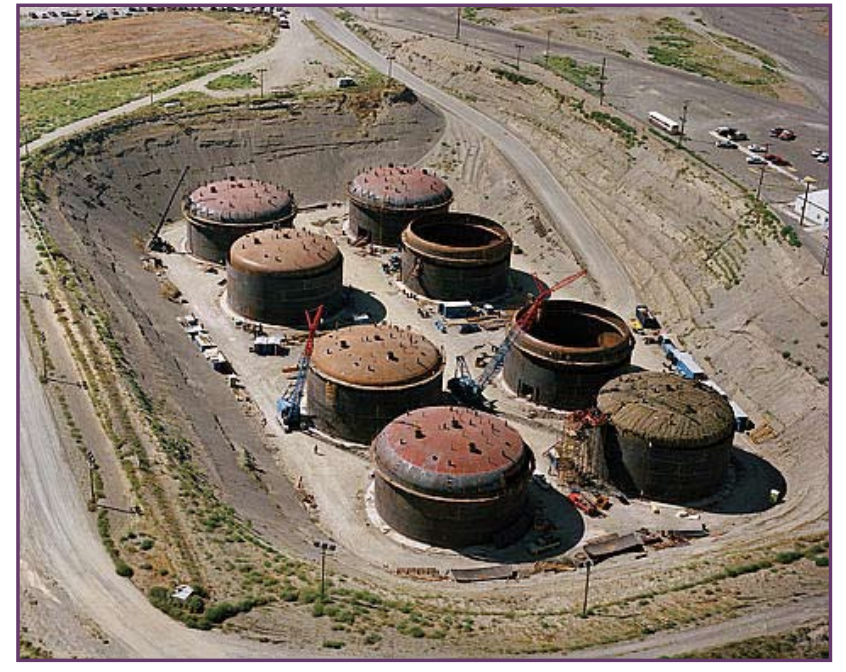

The 177 radioactive waste storage tanks were built at the Hanford Site between 1943 and 1985.

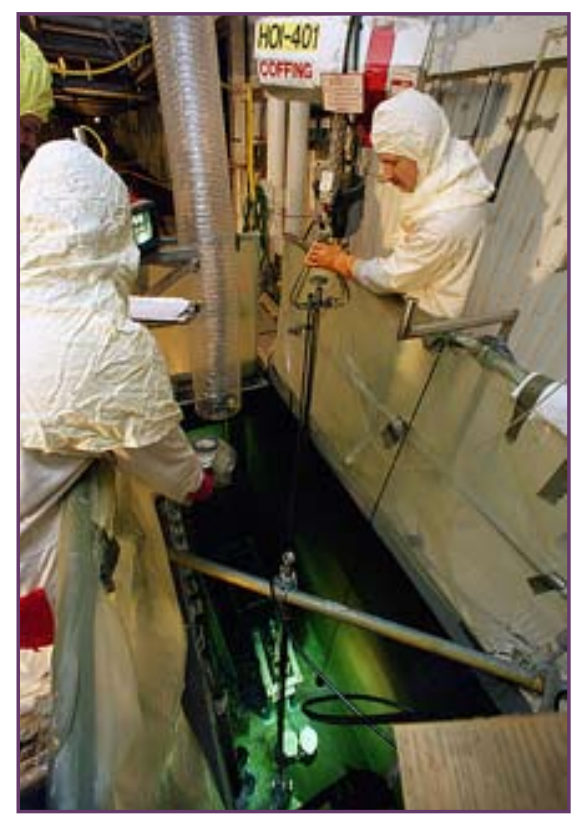

All of the spent fuel has been removed from the K-Basins and workers are now focused on removing the remaining sludge and debris. lowing page. then backfilled.
In addition to newly generated waste, significant quantities of legacy waste remain from years of nuclear material production and waste management activities. Most legacy waste from past operations at the Hanford Site resides in RCRAcompliant waste sites or is stored in places awaiting cleanup and ultimate safe storage or disposal. Examples include highlevel radioactive waste stored in single-shell and double-shell underground waste storage tanks and transuranic waste stored in vaults and on storage pads.

100 Areas Waste Sites. Full-scale remediation of waste sites began in the 100 Areas in 1996 and continued in 2005 at the $100-\mathrm{B} / \mathrm{C}, 100-\mathrm{K}, 100-\mathrm{N}, 100-\mathrm{D}$, and $100-\mathrm{F}$ Areas, and in the 100-IU-2 and 100-IU-6 Operable Units (The 100-IU-2 and 100-IU-6 Operable Units cover areas near the Hanford town site. A total of 929,802 tons of contaminated soil from 100 Areas remediation activities were disposed at the Environmental Restoration Disposal Facility (near the 200-West Area) during 2005. Pump-and-treat systems operated to help remove contamination from groundwater. A summary of 2005 groundwater pump-and-treat operations is shown in the table on the fol-

K Basins Closure Activities. From February 1994 through 2005, work has continued to clean out the $\mathrm{K}$ Basins. The $\mathrm{K}$ Basins contained 2,300 tons of Hanford N Reactor spent fuel and a small quantity of irradiated single-pass reactor fuel (fuel from older Hanford reactors). Removal of the fuel was completed in 2005 and activities now focus on cleaning up the remaining 70.4 cubic yards of sludge and 300 tons of debris.

Former Waste Site. In 2005, additional remediation was necessary at one waste site, i.e., the Horseshoe Landfill located on the Fitzner/Eberhardt Arid Lands Ecology Reserve Unit of the Hanford Reach National Monument. Although this waste site was remediated in 1996, recent soil sampling indicated the presence of contaminants above soil cleanup standards. Excavation, completed in 2005, removed 11,630 tons of contaminated soil. The excavated soil was disposed of at the Environmental Restoration Disposal Facility. Following excavation, additional sampling verified that cleanup standards were achieved. The site was 


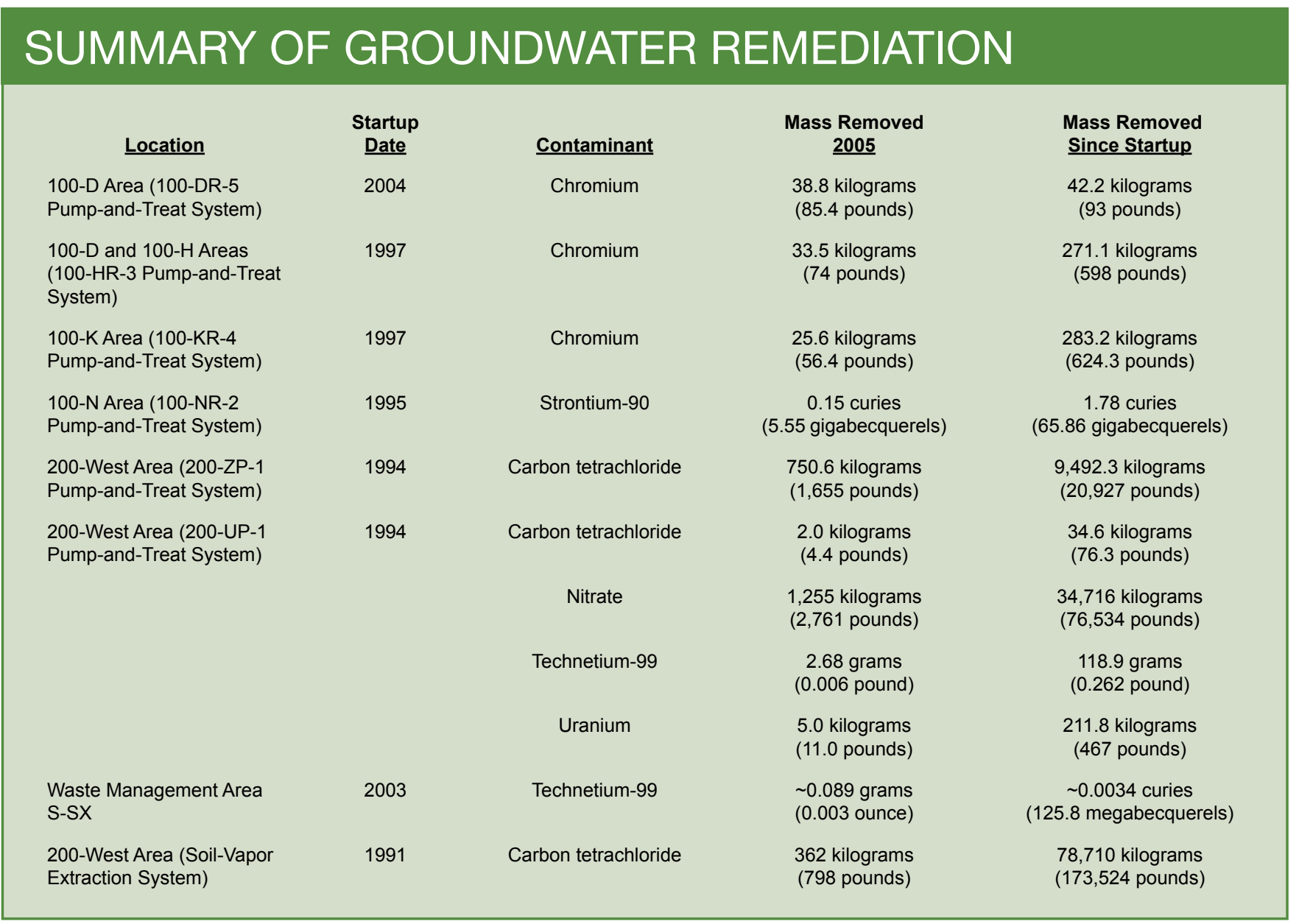

200 Areas Waste Sites. Remedial investigations or feasibility studies continued on various facilities in the 200 Areas in preparation for cleanup and closure. Pump-and-treat and soil-vapor extraction systems operated to help remove contamination from groundwater.

300 Area Waste Sites. Remediation efforts in 2005 focused on the 300-FF-2 Operable Unit waste sites. In 2005, 86,057 tons of contaminated soil from 300-FF-2 Operable Unit remediation were removed and disposed of at the Environmental Restoration Disposal Facility. Significant challenges for remediation are present at the 618-10 and 618-11 burial grounds. Efforts are underway to design a solution for remediation of these areas.

\section{FACILITY DECOMMISSIONING}

100 Areas Facilities. Decontamination and decommissioning activities continued during 2005 in the $100-\mathrm{K}, 100-\mathrm{H}$, and $100-\mathrm{N}$ Areas. The interim safe storage of the $\mathrm{H}$ Reactor was completed in 2005. These activities were conducted as non-time-critical removal actions under CERCLA. 


\section{What is decommissioning?}

When the DOE declares a facility as surplus (no longer needed) it is shut down and prepared for decontamination and decommissioning ( $D \& D)$. The process is the safe decontamination, dismantling, removal of contamination and structures, and/or the release for reuse of facilities that are no longer active. The DOE is conducting D\&D activities on reactors, processing plants, storage tanks, laboratory facilities, and other structures. Decontamination and decommissioning presents many challenges. Work continues at the Hanford Site to decommission facilities in the operational areas.

Adapted From

http://www.web.em.doe.gov/emprimer/ erdd.html
Facilities demolished in the $100-\mathrm{N}$ and $100-\mathrm{K}$ Areas during 2005 included the $1900-\mathrm{N}$ water tanks, $1802-\mathrm{N}$ pipe trestle, and the 183-KW and 183.1-KW water treatment facilities.

200 Areas Facilities. Decommissioning activities continued in the 200 Areas during 2005. Disposition of 200 Areas facilities includes the surveillance, maintenance, and deactivation of buildings and waste sites in the 200-East, 200-West, and 200-North Areas.

Facilities include interim status RCRA treatment, storage, and disposal units awaiting closure, the canyon facilities (PUREX Plant, B Plant, T-Plant, REDOX Plant, and U Plant), two operating major air emission units, and three operating minor emission stacks.

Surveillance, maintenance, and decontamination or stabilization of over 500 waste sites including former cribs, ponds, ditches, trenches, unplanned release sites, and burial grounds continued in 2005. Periodic surveillances, radiation surveys, and herbicide applications were performed at these sites and timely responses to identified problems were initiated. The overall objective was to maintain these sites in safe and stable configurations and to prevent contaminants at these sites from spreading in the environment.

221-U Chemical Processing Facility. Removal of ancillary facilities at the 221-U Chemical Processing Facility began in November 2004 and demolition of 11 of the structures was completed in September 2005. The U Plant ancillary facilities decontamination and decommissioning project has lost its funding due to higher priority DOE needs and limited funding availability. Therefore, the CERCLA removal action for the U Plant ancillary facilities is on hold until additional funding is available.

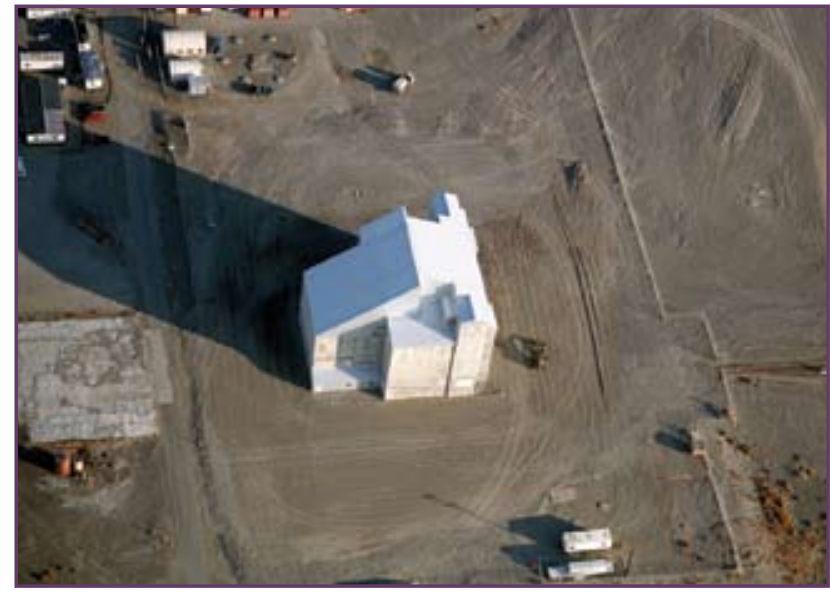

Interim safe storage of decommissioned reactors continued in 2005.
Plutonium Finishing Plant. Workers at the Plutonium Finishing Plant complex continued their work to stabilize, immobilize, repackage, and/or properly dispose of materials at the plant. The standard's laboratory was designated lowlevel waste status and closed in 2005. Removal of the three non-contaminated ancillary buildings that were part of the Plutonium Finishing Plant complex was completed. Other decontamination and characterization work continued during 2005.

\section{Using the 200 Areas Chemical Separations Plants for} Waste Disposal. The Canyon Disposition Initiative was created to investigate the potential for using the five canyon buildings (B Plant, T Plant, U Plant, PUREX Plant, and REDOX Plant) at the Hanford Site as disposal facilities for Hanford Site remediation waste, rather 
than demolishing the structures. In December 2004, a feasibility study and proposed plan were released for public review. These documents examined five alternatives for the remediation of the 221-U facility. In September 2005, the EPA issued their decision selecting the 'close-in-place collapsed structure' alternative as the preferred alternative. Under this alternative, equipment already in the U Plant will be consolidated into the below-ground U Plant process cells, the cells will be backfilled with grout, the exterior walls and roof will be collapsed in place, and the site will be covered with a barrier.

300 Area Facilities. During 2005, both the 324 and 327 Buildings were maintained in surveillance and maintenance mode in compliance with safety and regulatory requirements. However, at the 327 Building workers began to prepare for removing waste items to support a Tri-Party Agreement milestone.

During 2005, the 313 and 314 Buildings were demolished to slab, and the materials were disposed of at the Environmental Remediation Disposal Facility. The slabs and any underlying soil contamination will be addressed as part of a future remedial action.

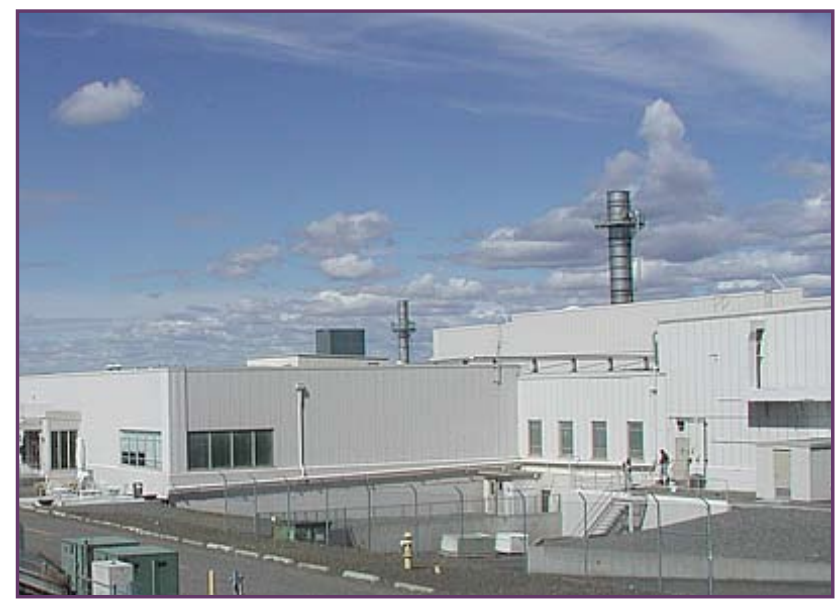

The 309 Plutonium Recycle Test Reactor was shut down in 1969. The facility is being maintained in a surveillance and maintenance mode to comply with safety and regulatory requirements.

400 Area Facilities - Fast Flux Test Facility. Decommissioning activities continued at the Fast Flux Test Facility in 2005. The final 13 interim spent nuclear fuel storage casks were fabricated and delivered. The remaining fuel was removed from the first of the two sodium filled spent fuel storage vessels. Sixty-nine fueled components were washed and packaged into ten interim storage casks; these components included three assemblies that required disassembly either to identify and isolate failed fuel pins or to facilitate the washing process to fully remove the sodium. Two of the interim storage casks were transferred to the 200 Areas Interim Storage Area while the remainder is stored in the 400 Area Interim Storage Area.

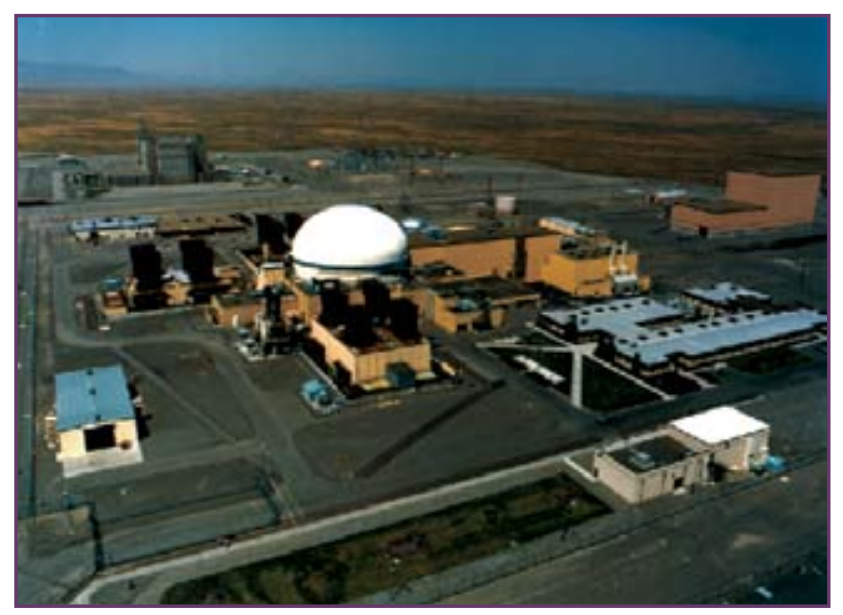

An access hole was drilled through the core support structure in the reactor

The Fast Flux Test Facility is being decommissioned. vessel to insert a suction pump. This was a DOE first-of-kind effort in which a drill bit at the end of a 50-foot-long drive line was used to drill into the stainless steel core support structure that was immersed in molten sodium. The drilling allowed access to molten sodium within the support structure 
that would not readily drain. Subsequently, approximately 42,300 gallons of sodium were pumped from the reactor vessel to the Sodium Storage Facility. In addition, 31,000 gallons of sodium were transferred from the Fuel Storage Facility vessel to the Sodium Storage Facility. In total, 224,200 gallons of Fast Flux Test Facility sodium are now stored in the Sodium Storage Facility tanks. The sodium has been allowed to cool and solidify in the tanks. About $15 \%$ of the original sodium remains in the Fast Flux Test Facility with twothirds of that in the remaining fuel storage vessel and the remainder characterized as "residual sodium."

\section{WASTE MANAGEMENT}

Waste management involves treating, storing, disposing of, shipping, handling, and monitoring waste at many Hanford locations.
A summary of liquid and solid waste treated, stored, or disposed of at Hanford in 2005 is provided in the table below. Waste management at the Hanford Site in 2005 included the treatment, storage, and disposal of solid waste at many Hanford locations.

Solid Waste Management. Solid waste management includes the treatment, storage, and/or disposal of solid waste produced as a result of Hanford Site operations or received from offsite sources that are authorized by the DOE to ship waste to the site. Onsite solid waste facilities include the Central Waste Complex, Waste Receiving and Processing Facility, T Plant complex, Environmental Restoration Disposal Facility, and Radioactive Mixed Waste Disposal Facility.

Waste is received at the Central Waste Complex in the 200-West Area from sources at the Hanford Site and any offsite sources that are authorized by the DOE to ship waste to the Hanford Site for treatment, storage, and disposal.

\section{HANFORD SITE WASTE SUMMARY 2005}

Activity

Waste generated during onsite cleanup activities

Waste received at Hanford from off the site

Waste shipped off the Hanford Site

Waste volume pumped from underground single-shell waste storage tanks

Waste volume in underground single-shell waste storage tanks at the end of 2005

Waste volume evaporated at the 242-A evaporator

Waste generated at Hanford and added to underground double-shell waste storage tanks

Waste volume in underground double-shell waste storage tanks at the end of 2005

\section{Waste Type}

Solid mixed waste

Radioactive waste

Solid mixed waste

Radioactive waste

Dangerous waste

Liquid waste

Liquid waste

Liquid waste

Liquid waste

Liquid waste
Amount

770,500 pounds

2.6 million pounds

419,000 pounds

183,300 pounds

401,700 pounds

234,714 gallons

30.2 million gallons

186,700 gallons

969,000 gallons

26.14 million gallons 
Ongoing cleanup, research, and development activities on the Hanford Site generate most of the waste received at this facility. Offsite waste is primarily from other DOE sites and U.S. Department of Defense facilities. The characteristics of the waste received vary greatly and it includes low-level, transuranic, or mixed waste, and radioactively contaminated PCBs. The Central Waste Complex can store as much as 734,418 cubic feet of waste. Treatment reduces the amount of waste in storage and makes room for newly generated mixed waste.

Waste destined for the Waste Receiving and Processing Facility includes stored waste as well as newly generated waste from current site cleanup activities. The waste consists primarily of contaminated cloth, paper, rubber, metal, and plastic. This facility, which began operating in 1997, dispositioned and shipped offsite 55,442 cubic feet of waste during 2005.

The T Plant complex in the 200-West Area provides waste treatment, storage, and decontamination services for the Hanford Site as well as for offsite facilities. T Plant complex currently operates under RCRA interim status.

Throughout 2005, approximately 1 million tons of remediation waste were disposed at the Environmental Restoration Disposal Facility. A total of approximately 6.3 million tons of remediation waste have been placed in the Environmental Restoration Disposal Facility from initial operations start-up in July 1996 through 2005. The total available expansion area of the facility site was authorized in a 1995 record of decision to cover as much as 1.6 square miles.

The Radioactive Mixed Waste Disposal Facility consists of two trenches in the 200-West Area. Disposal to the first trench began in September 1999 and the first layer of waste packages has been completed and covered with sand and gravel. The second waste layer has been started. Currently, there are approximately 137,700 cubic feet of waste in the first trench. There are approximately 4,600 cubic feet of waste disposed in the second trench, which was opened for operations in July 2004.

There were no defueled reactor compartments from the U.S. Navy shipped to trench 94 in 2005. The total number of Navy reactor compartments disposed at the trench remains at 114 .

Liquid Waste Management. Facilities are operated on the Hanford Site to store, treat, and dispose of various types of liquid

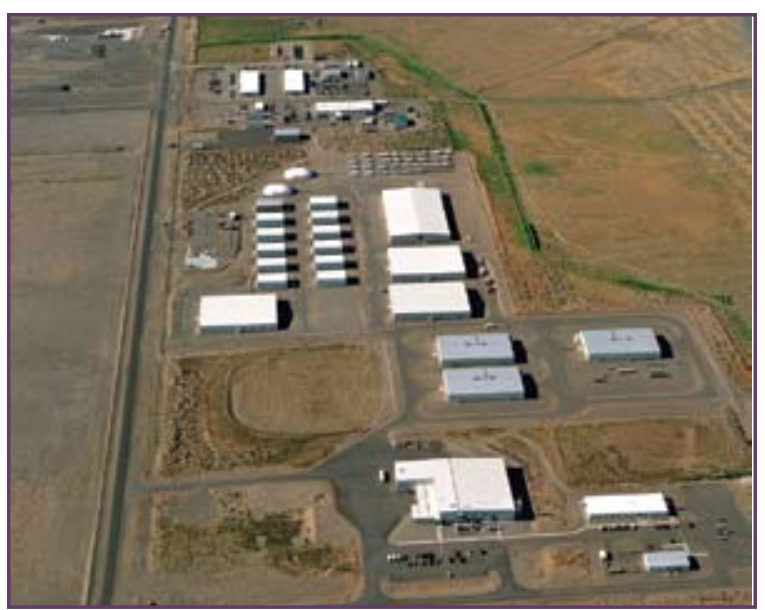

The Central Waste Complex receives waste from Hanford Site cleanup activities and from other DOE and Defense Department facilities.

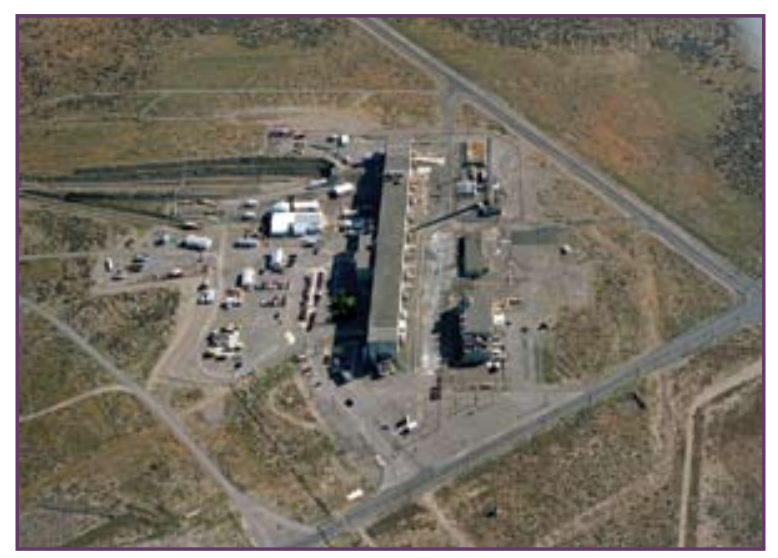

The T Plant complex operates under RCRA interim status. It provides waste treatment and storage and decontamination services for the Hanford Site.

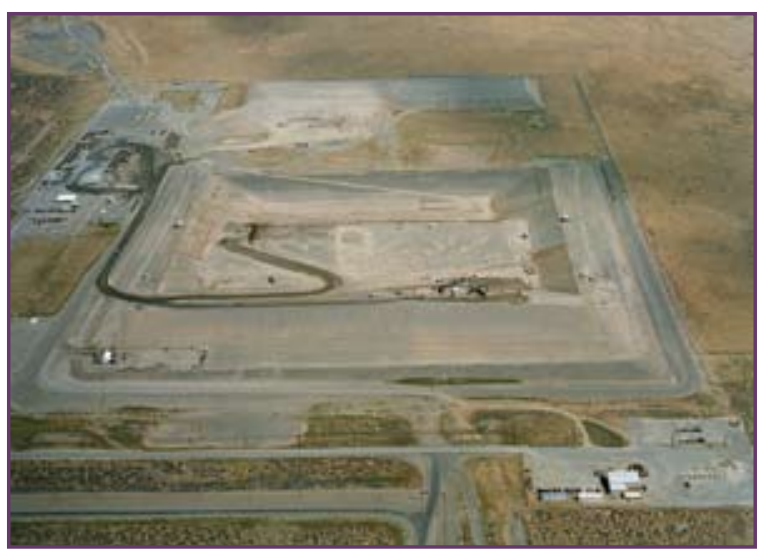

By the end of 2005, the Environmental Restoration Disposal Facility had received 6.3 million tons of contaminated soil and other waste from site cleanup operations. 


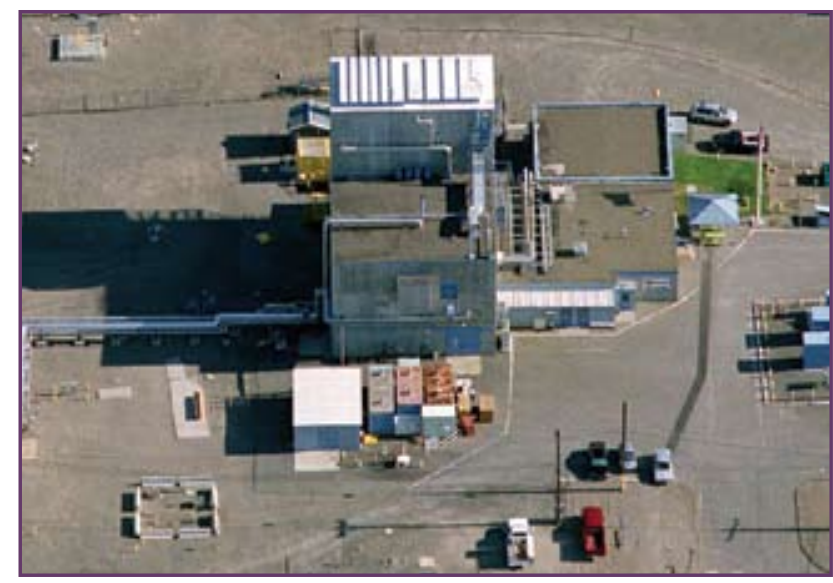

The 242-A evaporator processes dilute liquid tank waste into a concentrate.

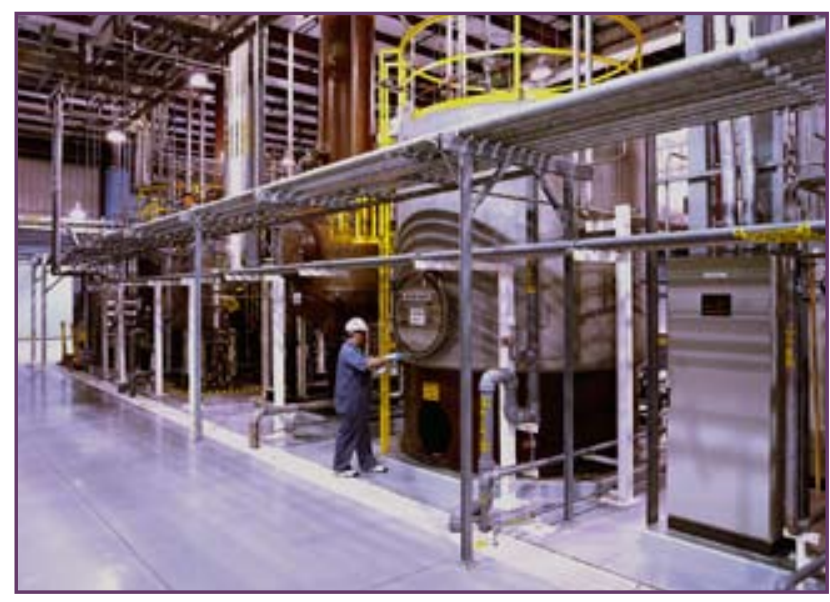

The Effluent Treatment Facility in the 200-East

Area treated and disposed of 6.3 million gallons of waste water during 2005.

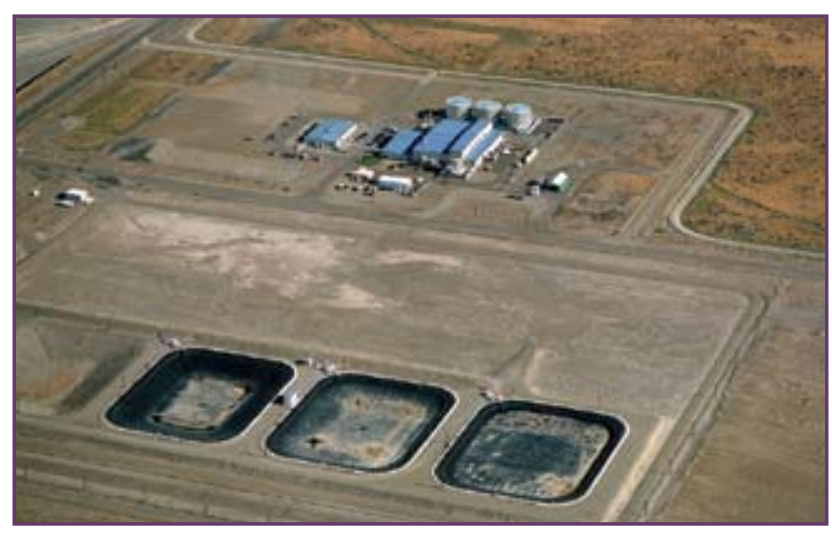

The three basins at the Liquid Effluent Retention Facility are lined with two, flexible, highdensity polyethylene membranes. waste generated by site cleanup activities. These facilities are operated and maintained in accordance with state and federal regulations and facility permits.

The 242-A evaporator in the 200-East Area concentrates dilute liquid tank waste by evaporation. This reduces the volume of liquid waste sent to the double-shell tanks for storage and reduces the potential need for more double-shell tanks. The 242-A evaporator completed one campaign during 2005. The volume of waste treated was 519,300 gallons, reducing the waste volume by 186,700 gallons, or approximately $36 \%$ of the total volume. The volume of process condensate transferred to the Liquid Effluent Retention Facility for subsequent treatment in the Effluent Treatment Facility was 197,000 gallons.

The Effluent Treatment Facility in the 200-East Area treats liquid effluent to remove toxic metals, radionuclides, and ammonia and to destroy organic compounds. The treated effluent is stored in tanks, sampled and analyzed, and discharged to the State-Approved Land Disposal Site (also known as the 616-A crib). The volume of wastewater treated and disposed of in 2005 was approximately 6.3 million gallons.

Approximately 10.29 million gallons of liquid waste were stored at the Liquid Effluent Retention Facility at the end of 2005. The volume of wastewater received for interim storage during 2005 was approximately 3.49 million gallons.

The 200 Area Treated Effluent Disposal Facility received 117 million gallons of unregulated effluent for disposal in 2005. The major source of this effluent was uncontaminated cooling water and steam condensate from the 242-A evaporator.

Industrial wastewater generated throughout the Hanford Site is collected and treated in the 300 Area Treated Effluent Disposal Facility. The wastewater consists of once-through cooling water, steam condensate, and other industrial wastewater. The volume of industrial wastewater treated and disposed of during 2005 was 35.88 million gallons.

Underground Waste Storage Tanks. The Office of River Protection manages the DOE's River Protection Project, which is responsible for the storage, retrieval, treatment, 
and disposal of high-level tank waste and the closure of tank farms on the Hanford Site. Much of the waste stored at Hanford is contained in large underground single-shell (one wall) and double-shell (two walls) tanks. These tanks are located in the 200 Areas; a grouping of tanks is referred to as a tank farm. The single-shell tanks are older, and some are known to have leaked. Liquid in the single-shell tanks is being transferred to double-shell tanks to prevent additional environmental releases.

During the year, 960,000 gallons of waste were pumped from single-shell tanks into the double-shell tank system. At the end of 2005, there were 26.1 million gallons of waste in the double-shell tanks.

Hanford Waste Treatment and Immobilization Plant (Waste Treatment Plant). The Waste Treatment Plant is being built on 65 acres located on the Central Plateau outside of 200-East Area to treat radioactive and hazardous waste currently stored in 177 underground waste storage tanks.

Currently, four major facilities are being constructed: a pretreatment facility, a high-level waste vitrification facility, a low-activity waste vitrification facility, and an analytical laboratory. Supporting facilities also are being constructed.

Engineering and construction activities for all facilities progressed in 2005, although technical challenges and funding cuts slowed both design and construction. New seismic design criteria for the pretreatment and high-level waste vitrification facilities, resolution of technical concerns, and reduced funding from Congress slowed the project and changed the work priorities in late 2005.

During 2005, the following activities were completed:

- Completed structural construction of the low-activity waste vitrification facility with installation of the facility's uppermost structural steel beam at the 68-foot elevation.

- Received 21 process vessels and installed 15 in the pretreatment facility.

- Finished installing, welding, and testing underground radioactive-waste transfer lines between the pretreatment and high-level waste vitrification facilities.

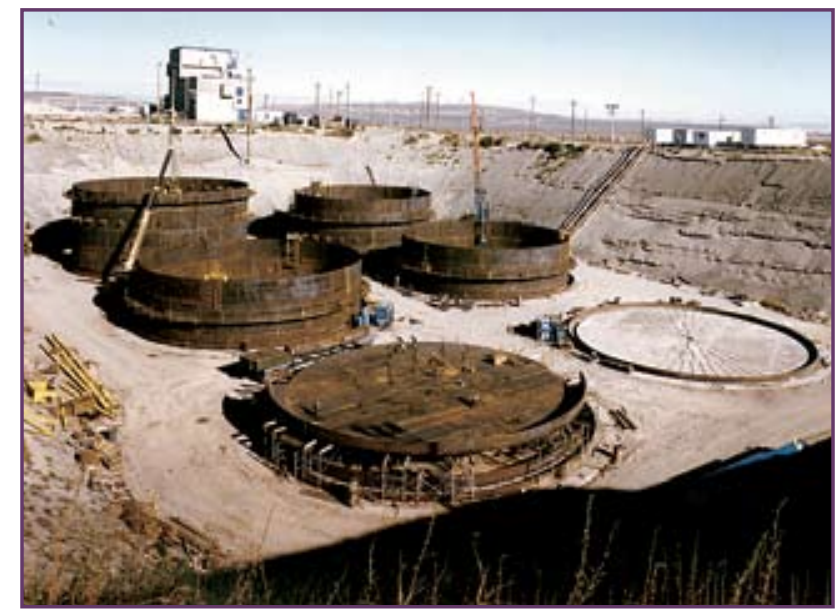

This photograph shows construction of six double-shell tanks being built in the 200 East Area of the Hanford Site in about 1975.

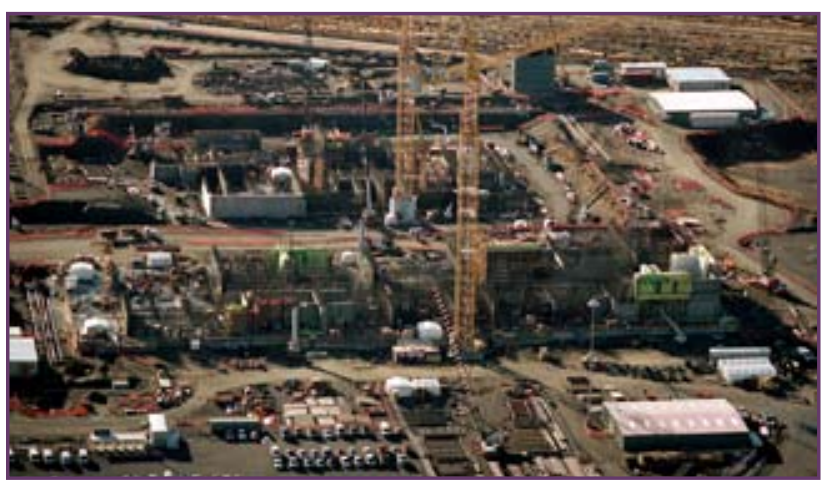

Engineering and construction activities for the Waste Treatment Plant progressed in 2005, although technical challenges and funding cuts slowed both design and construction.

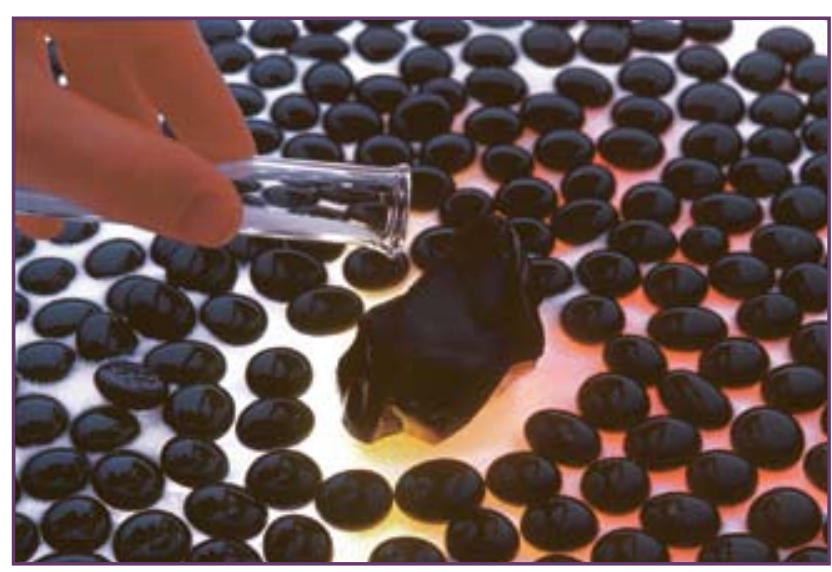

Waste vitrification chemically processes heavy metals and radioactive elements into a durable, leach-resistant glass. 
During 2005, workers

at the Waste Treatment

plant installed more than

159,000 feet of piping

and 32,000 tons of rebar

and poured 768,000 chbic

yards of concrete.
- Installed specialized viewing window frames for the laboratory's 14 hot cell process areas (areas where radioactive samples are processed remotely).

- Completed construction of eight above ground tanks for diesel fuel storage, water storage and treatment, and completed construction of three buildings comprising over 120,000 square feet for offices, warehouses, and workshops.

- Tested for durability two high-level vitrified waste canisters of different wallthicknesses. One canister had a 3/8-inch-thick stainless steel wall, while the other was constructed of 1/8-inch-thick stainless steel. Both were dropped 23 feet onto a 8-foot-thick concrete and steel pad. Post-drop integrity tests showed that both canisters met the durability criteria. By using the thinnerwalled canister, which holds more waste, the total number of canisters produced during the life of the facility will be reduced by about 500 .

Through the end of 2005, workers at the Waste Treatment Plant had installed the following commodities:

- 168,000 cubic yards of concrete.

- 199,000 feet of piping.

- 366,000 feet of electrical raceway.

- 207 tons of ductwork for heating, ventilating, and cooling.

- 32,000 tons of structural rebar.

- 2,949 tons of embedded steel plates.

- 8,100 tons of structural steel.

\section{SITE CLOSURE ACTIVITIES}

The principal requirements for the control and release of property at Hanford containing residual radioactivity are given in DOE Order 5400.5, Radiation Protection of the Public and the Environment. These requirements help ensure that property is evaluated; radiologically characterized and decontaminated before release; the level of residual radioactivity in property to be released is as near background levels as is reasonably practicable and meets DOE authorized limits; and all property releases are appropriately certified, verified, documented, and reported; public participation needs are addressed; and processes are in place to appropriately maintain records. No property with detectable residual radioactivity was released from the Hanford Site in 2005. 
Hanford Reach National Monument. The Hanford Reach National Monument lies within the boundaries of the Hanford Site. Although the DOE maintains administrative control over the land within the monument, the U.S. Fish and Wildlife Service manages about $84 \%$ of the monument land. In 2001, the DOE Office of Inspector General concluded that 143,000 acres of land within the monument could be transferred to the U.S. Department of Interior without adversely affecting DOE operations on the Hanford Site. Subsequently, the DOE Richland Operations Office entered into negotiations with the U.S. Department of Interior regarding release and transfer of selected portions of the monument from DOE control to the jurisdiction of the U.S. Fish and Wildlife Service. The necessary processes and assessments to make that happen are currently underway.

Emergency Decontamination Facility. The Emergency Decontamination Facility maintained next to Kadlec Medical Center in Richland is no longer needed because other decontamination facilities have been constructed. On May 4, 2005, the DOE returned control of the facility to Kadlec Medical Center.

Columbia River Corridor. Activities continued during 2005 to clean up the Columbia River Corridor. Although risk assessments are usually done prior to cleanup activities, the regulatory agencies have granted interim records of decision to initiate cleanup first and postpone conducting risk assessments until a later date. In 2005, sampling began on the 100 Areas and 300 Area baseline risk assessment. Planning was initiated for the inter-areas component and the Columbia River component of baseline risk assessments. A website was created to provide information about past and ongoing risk assessments and cleanup activities along the river corridor. The site includes the dates of public involvement opportunities, documents available for review and comment, administrative information, and links to related projects. The website can be found at http://www.washington closure.com/projects/endstate.

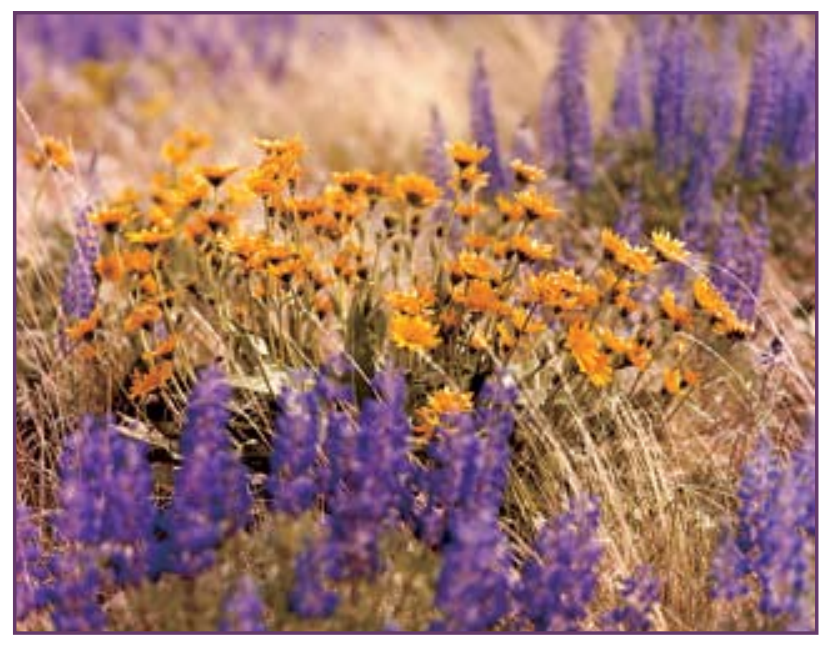

Cusick's sunflower (yellow) and the surrounding lupine (purple) are both native to the Hanford Site and can be found on the lower slopes of Rattlesnake Mountain in the Hanford Reach National Monument.

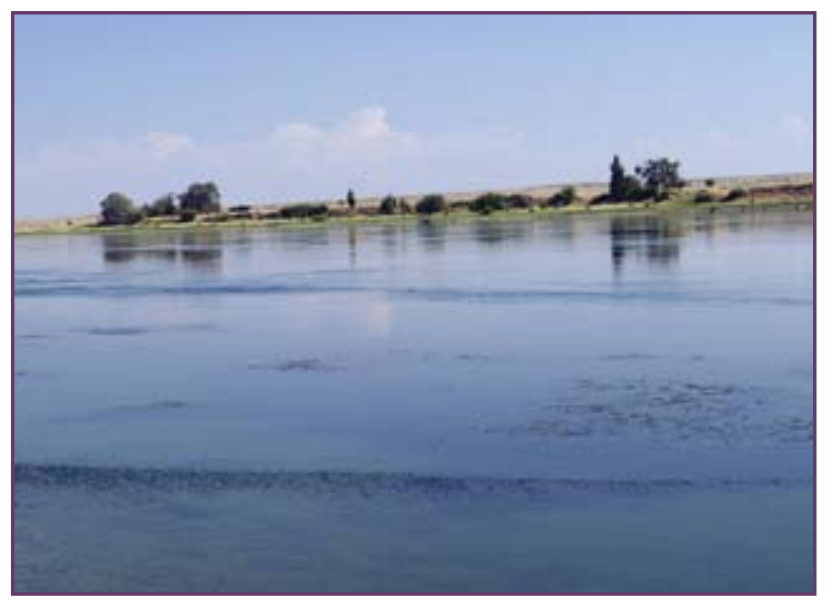

The mission of the DOE Office of River Protection is to retrieve and treat Hanford's tank waste and close the tank farms to protect the Columbia River Corridor. 


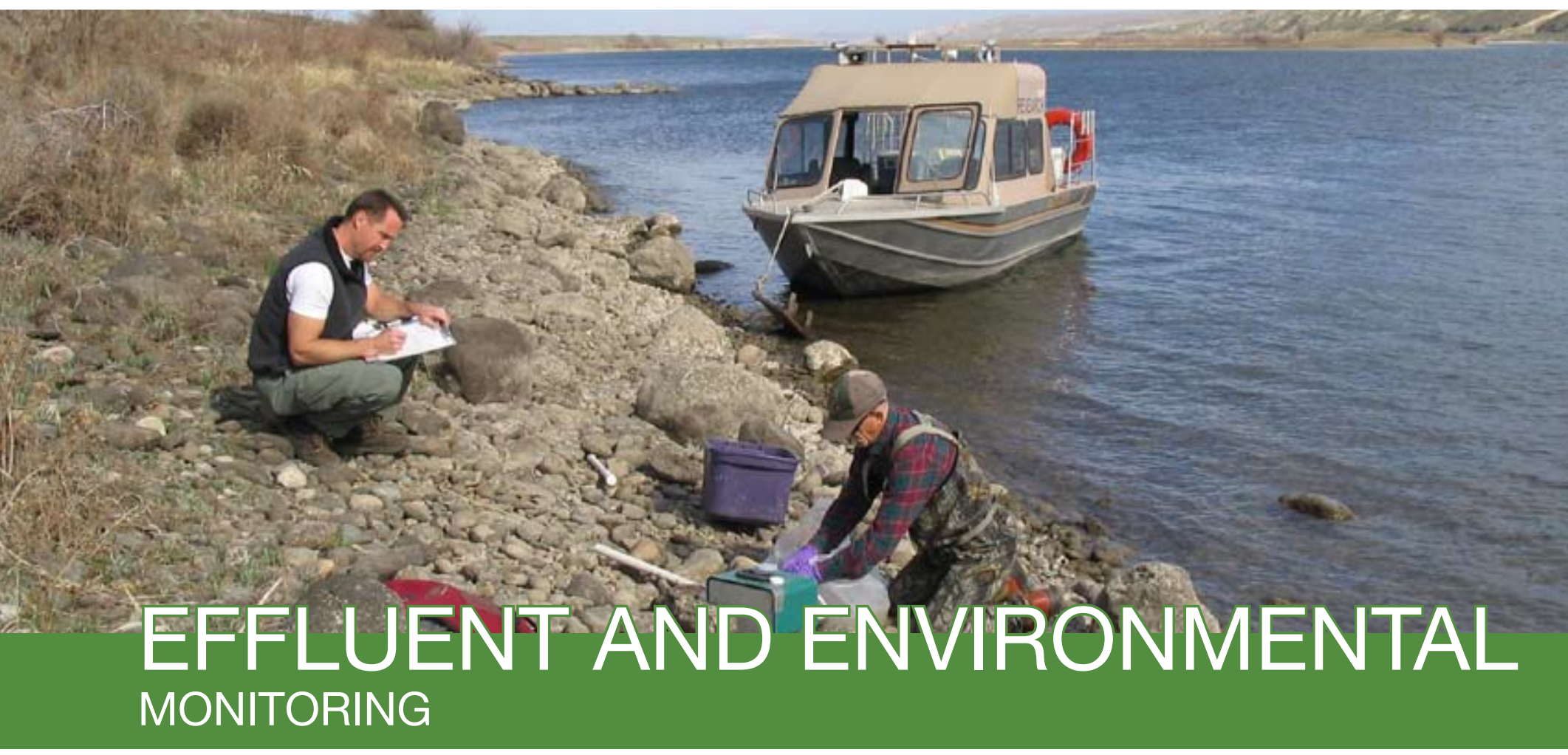

Water samples are collected at aquifer tubes along the Columbia River shoreline.

Effluent monitoring includes analysis of environmental samples collected near major nuclear-related installations, waste storage and disposal units, and remediation sites. This near-facility monitoring program is designed to evaluate and report analytical data, determine the effectiveness of facility effluent monitoring and controls, measure the adequacy of containment at waste disposal sites and detect and monitor unusual conditions. In addition to sampling such things as air, soil, vegetation, external radiation levels and surface contamination; liquid effluent and airborne emissions are monitored at all facilities that have the potential to discharge, or have discharged, stored, or been a disposal site for, radioactive and hazardous materials. Effluent monitoring is conducted by the facility operating contractor or designated subcontractor.

Environmental monitoring is conducted independent of the operating contractors and subcontractors. The purpose of environmental monitoring is to monitor the Hanford environment, provide assurance that the site operates in compliance with applicable environmental regulations, and conduct impact assessments for public and worker safety as well as to evaluate Hanford's significant ecological and cultural resources. The projects obtain environmental information related to public health and environmental effects that is necessary for the DOE to manage environmental risk at the Hanford Site. 
Environmental monitoring consists of sampling and analyzing various media on and around the site to detect potential contaminants. Workers sample various media including agricultural products, air, fish and wildlife, soil, surface water and sediment, Columbia River shoreline spring water and sediment, and vegetation. The samples are analyzed for radionuclides and chemicals. Environmental and resource monitoring includes monitoring the following: surface environment, meteorology, cultural resources, ecology, groundwater, and drinking water.

The primary environmental and resource monitoring programs and projects at Hanford include the Effluent Monitoring Program, conducted by Fluor Hanford, Inc.; the Public Safety and Resource Protection Project, managed by the Pacific Northwest National Laboratory; and the Groundwa-

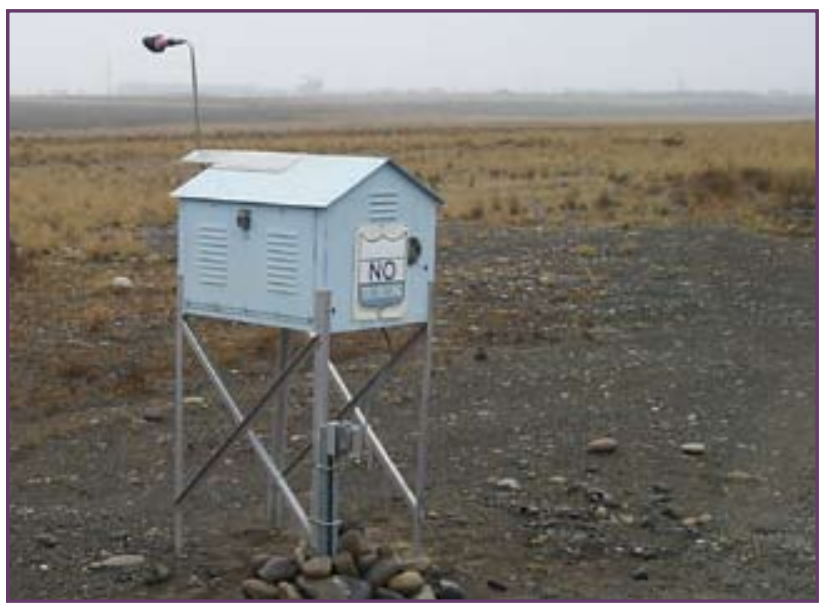

Air samplers on the site were located primarily around major operational areas to maximize the ability to detect radiological contaminants resulting from site operations. ter Performance Assessment Project, also managed by Pacific Northwest National Laboratory. Hanford Site drinking water is monitored for radiological contaminants by Pacific Northwest National Laboratory personnel through a contract with Fluor Hanford, Inc. The Biological Control Program is managed by Fluor Hanford, Inc.

\section{EFFLUENT MONITORING}

Effluent monitoring at Hanford has two elements: (1) liquid effluent and airborne emissions monitoring at site facilities and operations and (2) environmental monitoring near facilities and operations.

Liquid Effluent and Airborne Emissions. Liquid effluent and airborne emissions that may contain radioactive or hazardous constituents are continually monitored at the Hanford Site. Facility operators perform the monitoring mainly through analyzing samples collected at points of release into the environment. Monitoring data are evaluated to determine the degree of regulatory compliance for each facility and/or the entire site. These evaluations are also used to assess the effectiveness of effluent treatment and pollution-management practices.

In 2005, the State-Approved Land Disposal Site in the 200 Area was the only facility that discharged radioactive liquid effluent to the ground. Nonradioactive hazardous materials in liquid effluent were discharged to both the State-Approved Land Disposal Site and to the Columbia River at designated (permitted) discharge points.

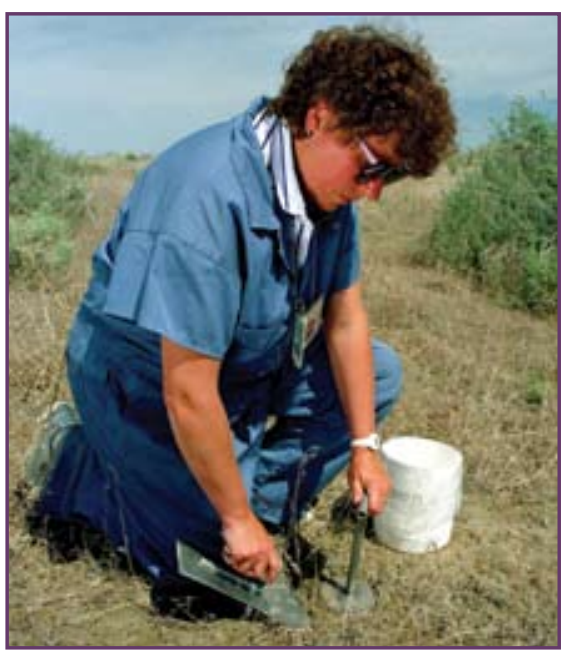

Soil samples were collected near waste disposal sites and from locations downwind and near or within the boundaries of operating facilities and remediation sites. 
Radioactive air emissions usually come from a building stack or vent. In 2005, radioactive emission discharge points were located in the 100, 200, 300, 400, and 600 Areas.

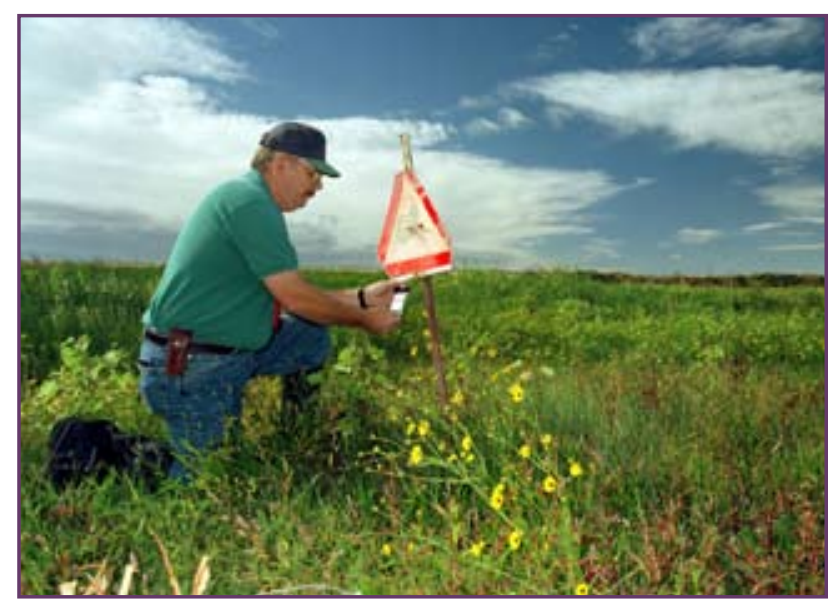

Near-Facility Environmental Monitoring. Near-facility monitoring is conducted adjacent to DOE facilities and operations on the Hanford Site that have the potential to discharge, or have discharged, stored, or been a disposal site for, radioactive or hazardous contaminants. The monitoring program consists of collecting and analyzing environmental samples and conducting radiological surveys in areas near facilities. The program also is designed to evaluate and report analytical data, determine the effectiveness of facility effluent monitoring and controls, measure the adequacy of containment at waste disposal sites, and detect and monitor unusual conditions.
In 2005, scientists evaluated potential radiological doses to the public and biota resulting from exposure to Hanford Site liquid effluents and airborne emissions.

\section{Meteorological}

meashrements are taken

to shpport Hanford site

emergency preparedness

and response, site

operations, and atmospheric

dispersion calculations for

dose assessments.
Air, soil, vegetation, and biota are routinely sampled near Hanford Site facilities and various radiological and non-radiological measurements are taken. In addition, surface contamination and external radiation levels are monitored. Active and inactive waste disposal sites and the terrain surrounding them are surveyed to detect and characterize radioactive surface contamination. During 2005, there were several locations on the Hanford Site where samples were collected: 88 locations for air samples, 97 locations for soil samples, 62 locations for vegetation samples, and 136 locations where external radiation was measured.

\section{ENVIRONMENTAL MONITORING}

The early identification of, and appropriate response to, activities that could have potentially adverse effects on the environment and resources are assured by routinely conducting pre-operational environmental characterization and assessment activities; performing environmental monitoring; monitoring cultural resources; performing periodic sampling of Hanford Site drinking water; and monitoring and controlling contaminated and undesirable biota. The table on the facing page provides the results of 2005 environmental monitoring.

Climate and Meteorology. Meteorological measurements support Hanford Site emergency preparedness, site operations, and atmospheric dispersion calculations. Activities include weather forecasting and maintaining and distributing climatological data.

The average temperature for 2005 was $53.5^{\circ} \mathrm{F}$, which was $0.1^{\circ} \mathrm{F}$ below normal $\left(53.6^{\circ} \mathrm{F}\right)$. Five months during 2005 were warmer than normal; five months 


\section{HANFORD SITE MONITORING RESULTS FOR 2005}

\section{What was Monitored?}

Air

Columbia River Water and Sediment

Columbia River Shoreline Spring Water and Sediment

Food and Farm Products

Fish and Wildlife

Soil

Vegetation
Air particles and gases were analyzed for radioactive materials. Air was sampled at 23 site-wide locations on Hanford, 11 perimeter locations, 8 community locations, and in 2 distant communities. In addition, air samples were collected at 88 locations near Hanford Site facilities.

Columbia River water and sediment samples were collected from multiple sampling points throughout the year. The samples were analyzed for radioactive and chemical materials. Columbia River water quality met the Washington State designation for supporting "noncore salmon/trout" and is "usable for substantially all needs."

Groundwater discharges to the Columbia River via surface and subsurface springs. Discharges above the water level of the river are identified as shoreline springs. Samples of spring water and sediment were collected at locations along the Hanford shoreline of the Columbia River.

Samples of alfalfa, asparagus, cherries, honey, leafy vegetables, milk, potatoes, tomatoes, and wine were collected from locations upwind and downwind of the Hanford Site.

Game animals and other animals of interest on the site and along the Hanford Reach and fish from the Columbia River were monitored at onsite locations and three offsite reference locations. Carcass, bone, and muscle samples were analyzed to evaluate radionuclide levels.

Soil samples were collected at 97 locations near facilities in 2005 . Routine radiological monitoring at site-wide and offsite locations was last conducted in 2004.

Vegetation samples were collected near Hanford Site facilities in 2005. Vegetation samples were collected at site-wide and offsite locations in 2004.

\section{The Bottom Line}

All measurements of radioactive materials in air were below recommended guidelines. In general, radionuclide concentrations near facilities were at or near Hanford Site background levels, which are much less than DOE derived concentration guides but greater than concentrations measured off the site. The data also show that concentrations of certain radionuclides were higher and widely variable within different onsite operational areas.

As in past years, small amounts of radioactive materials were detected downriver from Hanford. However, the amounts were far below federal and state limits. During 2005, there was no indication of any deterioration of Columbia River water or sediment quality resulting from operations at Hanford.

Samples collected at the springs contained some contaminants at levels above those observed in near-shore river water but similar to local groundwater. However, concentrations in river water downstream of the shoreline springs remained far below federal and state limits. Contaminant concentrations in sediment samples from shoreline springs were similar to background levels, except for uranium at the 300 Area, which was roughly four times background.

Radionuclide concentrations in samples of food and farm products were at normal environmental levels.

Samples of bass, whitefish, geese, lizards, rabbits, mice, invertebrates, and elk were collected and analyzed. Radionuclide levels in wildlife samples were well below levels that are estimated to cause adverse health effects to animals or to the people who may consume them.

There were 97 routine soil samples collected onsite near facilities and operations in 2005. In general, radionuclide concentrations in samples collected from or adjacent to waste disposal facilities in 2005 were higher than concentrations measured in distant communities in 2004. There were 20 instances of radiological contamination in soil samples investigated in 2005. Of the 20 locations, 15 were cleaned up. At the remaining locations, the contamination levels did not exceed the radiological control limits for the sites and the soil was left in place.

Concentrations of radionuclides were elevated in vegetation samples obrtained near facilities when compared to concentrations in samples from distant communities collected in 2004.

were cooler than normal, and two were normal. March had the greatest positive departure, $2.8^{\circ} \mathrm{F}$ above normal; December, at $4.3^{\circ} \mathrm{F}$ below normal, had the greatest negative departure.

Precipitation during 2005 totaled 6.39 inches, which is $92 \%$ of normal (6.98 inches). Snowfall for 2005 totaled 12.1 inches, compared to normal snowfall of 15.4 inches. 


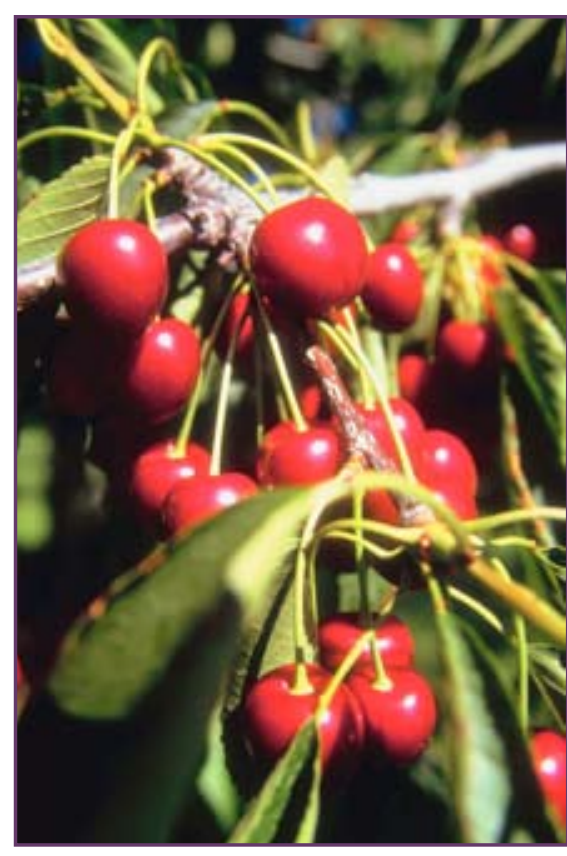

Samples of cherries and other agricultural crops were collected during 2005.

The DOE is making shre that significant cultural resontres are managed and maintained in a way that considers the preservation of their historic, archaeological, atrchitectural, and cultural values.
The average wind speed during 2005 was 7.1 miles per hour, which was 0.5 mile per hour below normal. The peak gust for the year was 61 miles per hour on March 16.

Two dust storms were recorded at the Hanford Meteorology Station during 2005. There has been an average of five dust storms per year at the Hanford Meteorology Station during the entire period of record (1945-2005).

Surface Environmental Surveillance Project. This project is responsible for measuring the concentrations of radiological and non-radiological contaminants in environmental media onsite (site-wide locations) and offsite at perimeter, community, and distance locations and assessing the potential effects of contaminants on the environment and the public. Samples of agricultural products, air, fish and wildlife, soil, surface water and river sediment, Columbia River shoreline spring water and sediment, and vegetation are collected routinely. The samples are analyzed for radionuclides and chemicals including metals and anions. Project monitoring activities focus on routine releases from DOE facilities on the Hanford Site; however, the project also conducts sampling and analysis in response to known unplanned releases and releases from non-DOE operations on and near the site. Monitoring results are provided to the DOE and the public annually through this report series. If elevated contaminant concentrations are found, they are reported to the DOE Richland Operations Office.

Ecological Monitoring and Compliance Project. This project supports both activity-specific ecological compliance requirements and site-wide requirements to assure the protection of Hanford's natural resources. Project personnel monitor the abundance, vigor, and distribution of plant and animal populations on the Hanford Site and evaluate the cumulative impact of site operations on these resources. In addition, project staff conduct baseline ecological resource surveys to document the occurrence of protected species, evaluate and document impacts to protected species and habitats, facilitate regulatory compliance, and evaluate fulfillment of DOE natural resource protection responsibilities. These activities are intended to protect the natural resources within the DOEoperated portions of the Hanford Site, including the DOE-managed portion of the Hanford Reach National Monument.

Cultural Resources. The DOE is responsible for managing and protecting the Hanford Site's cultural and historic resources. The Hanford Cultural and Historic Resources Program, which is maintained by the DOE, makes certain that cultural and historic resources entrusted to the DOE are managed responsibly and in accordance with applicable regulatory requirements.

Cultural resources reviews must be conducted before a federally funded, federally assisted, or federally licensed ground disturbance or building alteration/ demolition project can take place. As such, cultural resource reviews are 
required at Hanford to identify properties within the proposed project area that may be eligible for, or listed in, the National Register of Historic Places, and evaluate the project's potential to affect any such property. During 2005, 190 cultural resource reviews were requested.

Groundwater Performance Assessment Project. This project is responsible for assessing the distribution and movement of known ground water contamination (both radiological and chemical) beneath the Hanford Site and for identifying and characterizing potential and emerging groundwater contamination problems.

Evaluation of groundwater samples showed that groundwater contaminant plumes are continuing to move from beneath former waste sites to the Columbia River. The total area of radiological and chemical contaminant plumes with contaminant concentrations exceeding drinking water standards was estimated to be approximately 77 square miles during 2005 .

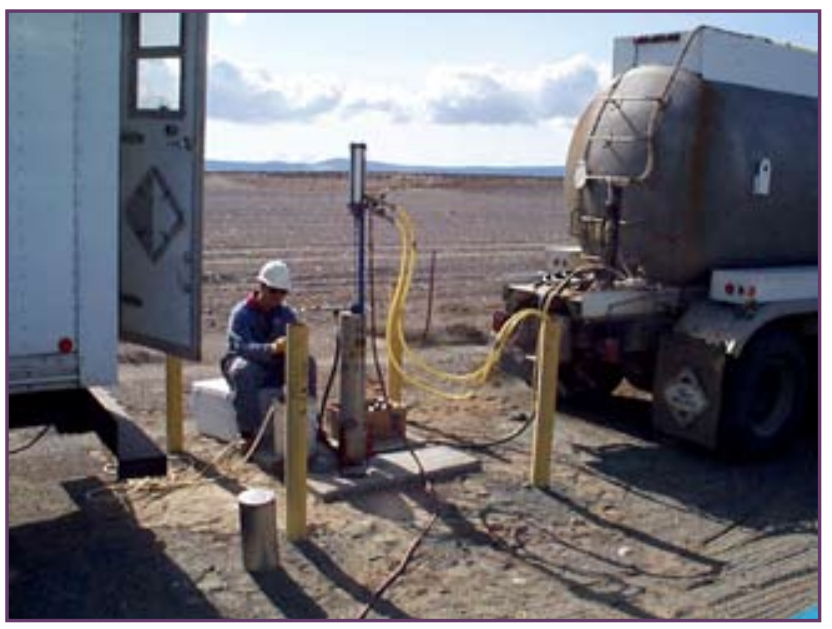
This area occupies $13 \%$ of the total area of the Hanford Site. The tritium and iodine-129 plumes have the largest areas with concentrations exceeding drinking water standards.

Drinking Water Monitoring Project. This project conducts radiological monitoring of DOE-owned, contractor-operated drinking water systems. There were 11 systems supplying drinking water to the Hanford Site during 2005. All system were in compliance with drinking water standards for radiological, chemical, and microbiological contaminant levels during 2005. All analytical results are reported routinely to the Washington State Department of Health.

Biological Control Program. Biological control is any activity to prevent, limit, clean up, or remediate the impact to the environment, or human health and safety, from contaminated or undesirable plants or animals. The Biological Control Program is responsible for integration of (1) expanded radiological surveillance for contaminated biota and soil, (2) control of undesirable plants and animals, (3) clean up of legacy and new contamination related to biota, and (4) remediation, following clean up, of sites affected by radioactive contamination spread by plants and animals.

Biological control personnel responded to approximately 30,000 animal control requests from Hanford employees in 2005. There were 20 contaminated animals or animal-related materials discovered during 2005. This is approximately 60\% less than the peak number of 46 in 1999 and is the same as the total for 2004.

Flying insects and insect material are also collected during operations on the

Groundwater samples were collected from 687 wells and 128 shoreline aquifer tubes to monitor contaminant concentrations. Water levels were measured in several hundred wells on the site to map groundwater movement.

Noxions weeds are controlled on the site to prevent their spread and eliminate populations. These meashres are applied to help ensure that entire uative plant communities are not destroyed, thas altering ecosystems. Hanford Site and tested for radiological contamination. Only one of the 
contaminated samples found in 2005 related to insects, i.e., a contaminated wasp nest found in a storage container in the $100-\mathrm{H}$ Area. There were no incidents of offsite contamination by animals during 2005, and all cases of new contamination reported onsite were cleaned up or scheduled for cleanup.

\section{POTENTIAL RADIOLOGICAL DOSES FROM 2005 HANFORD OPERATIONS}

During 2005, the potential radiological dose to the public from Hanford operations was evaluated to determine compliance with pertinent regulations and limits. The potential dose to the offsite maximally exposed individual in 2005 was 0.37 microsievert per year. The national average dose from background sources, according to the National Council on Radiation Protection, is approximately 3 millisievert per year, and the current DOE radiological dose limit for a member of the public is 1 millisievert per year.

\section{REPORT INQUIRIES}

Inquiries about this booklet or comments and suggestions about its content may be directed to Mr. D. C. (Dana) Ward, U.S. Department of Energy, Richland Operations Office, P.O. Box 550, Richland, Washington 99352 (Dana_C_Ward@rl.gov) or to Mr. R. W. (Bill) Hanf, K6-75, Pacific Northwest National Laboratory, P.O. Box 999, Richland, Washington 99352 (bill.hanf@pnl.gov).

Copies of this summary booklet and the 2005 report have been provided to many public libraries in communities around the Hanford Site and to several university libraries in Washington and Oregon. Copies also can be found at the DOE's Public Reading Room located in the Consolidated Information Center, Room 101L, in Richland, Washington. Copies of the 2005 report can be obtained from Mr. R. W. (Bill) Hanf, K6-75, Pacific Northwest National Laboratory, P.O. Box 999, Richland, Washington 99352 (bill.hanf@pnl.gov) while supplies last. The reports can also be accessed on the Internet at http://hanford-site.pnl.gov/envreport. 